\title{
1 Trypsin isozymes in the lobster Panulirus argus (Latreille, 1804): from molecules
}

\section{2 to physiology}

3

4 E. Perera ${ }^{1,4^{*} \dagger}$, L. Rodríguez-Viera ${ }^{1}$, R. Perdomo-Morales ${ }^{2}$, V. Montero-Alejo ${ }^{2}$, F.J. Moyano ${ }^{3}$, G.

5 Martínez-Rodriguez ${ }^{4}$, J.M. Mancera ${ }^{5}$

6

$7 \quad{ }^{1}$ Center for Marine Research, University of Havana, Havana, Cuba

$8 \quad{ }^{2}$ Biochemistry Department, Center for Pharmaceuticals Research and Development, Havana, Cuba

$9 \quad{ }^{3}$ Department of Applied Biology, University of Almeria, Almeria, Spain

$10{ }^{4}$ Instituto de Ciencias Marinas de Andalucía (ICMAN), CSIC, Cádiz, Spain

$11{ }^{5}$ Department of Biology, Faculty of Marine and Environmental Science, University of Cadiz, Spain

$12 *$ Corresponding author, ${ }^{\dagger}$ Current address: Instituto de Ciencias Marinas de Andalucía (ICMAN), CSIC, Apartado Oficial, 11510-

13 Puerto Real, Cádiz, Spain. Tel. +34 956832612 ext. 334, E-mail address: erick.perera@icman.csic.es; erickpbcim@yahoo.es (E.

14 Perera).

Running title: Trypsins in lobster: from molecules to physiology

\section{Abstract}

Trypsin enzymes have been studied in a wide variety of animal taxa due to their central role in protein digestion as well as in other important physiological and biotechnological processes. Crustacean trypsins exhibit a high number of isoforms. However, while differences in properties of isoenzymes are known to play important roles in regulating different physiological processes, there is little information on this aspect for decapod trypsins. The aim of this review is to integrate recent findings at the molecular level on trypsins enzymes of the spiny lobster Panulirus argus, into higher levels of organization (biochemical, organism) and to interpret those findings in relation to the feeding ecology of these crustaceans. Trypsin in lobster is a polymorphic enzyme, showing isoforms that differ in their biochemical features and catalytic efficiencies. Molecular studies suggest that polymorphism in lobster trypsins may be nonneutral. Trypsin isoenzymes are differentially regulated by dietary proteins, and it seems that some isoenzymes have undergone adaptive evolution coupled with a divergence in expression rate to increase fitness. This review highlights important but poorly studied issues in crustaceans in general, such as the relation among trypsin polymorphism, phenotypic (digestive) flexibility,

33 digestion efficiency, and feeding ecology.

34 Keywords: digestion biochemistry; ecological physiology; Panulirus argus; protein digestion; trypsin 
38 Trypsin and trypsin-like enzymes have been the subjects of a huge amount of studies due to

39 their central role in protein digestion as well as in other important physiological (e.g. blood

40 coagulation, fibrinolysis, development, fertilization, apoptosis and immunity, Page and Di Cera

41 2008), and biotechnological processes (Anheller et al. 1989; Nyberg et al. 2006; Shahidi and

42 Kamil 2001; Bougatef 2013). Historically, the most studied trypsin is the bovine trypsin since it

43 was purified by crystallization at the beginnings of the 1930s (Northrup and Kunitz 1931), and

44 then characterized (Northrub et al. 1948) and sequenced (Walsh et al. 1964; Walsh and Wilcox 1970). The three-dimensional structure of the bovine trypsin was resolved in the 1970s by X-ray crystallography (Huber et al. 1974; Sweet et al. 1974; Kossiakoff et al. 1977), and further research during the last decades has expanded the knowledge of this enzyme in terms of catalysis, structure-function relationship, evolution, and regulatory mechanisms (Perona and Craik 1995; Hedstrom 1996; Thimister et al. 1996; Page and Di Cera 2008). In addition, trypsins and trypsin-like serine peptidases have been studied in a wide variety of other animal taxa (Borovsky 2003; Srinivasan et al. 2006; Rascón et al. 2011), including several crustaceans (Muhlia-Almazán et al. 2008; Carrillo et al. 2008; Sainz and Córdova-Murueta 2009). Trypsins are the main digestive endopeptidases in most crustaceans, although in some species other proteinases are predominantly expressed. Caridean shrimps such as Crangon crangon and Crangon allmani showed extremely variable levels of tryptic activity, with some shrimp showing very low or none tryptic activities, while cysteine proteinases such as cathepsin L-like enzymes dominates in their midgut gland (Teschke and Saborowski 2005).

The Nomenclature Committee of the International Union of Biochemistry and Molecular Biology (NC-IUBMB) grouped in 1992 the serine peptidases of crustaceans under the term brachyurins (EC 3.4.21.32) (Tsu and Craik 1998; Barret et al. 1998) that include three different types: Ia, Ib and II. Type Ia brachyurins exhibit wide specificity, including trypsin, chymotrypsin and elastase activity, and they are known as crustacean collagenolitic serineproteases. Type Ib brachyurins share the specificity of type Ia, but with a drastic reduction of the trypsin activity, being known as crustacean chymotrypsins. Type II brachyurins are enzymes with strict trypsin specificity, they are referred as crustacean trypsins and, as all other trypsins, they belong to the clan PA, family S1 (MEROPS database: URL: http://www.merops.co.uk).

68 Trypsins have a catalytic triad composed by the residues His57, Asp102 and Ser195

69 (chymotrypsin nomenclature) and cleave peptide bounds at the carboxylic side of the residues 70 Arg and Lys in P1 position of proteinaseous substrates (Stryer 1988). 
72 The remarkable distinct features of crustacean collagenolytic serine proteases have prompted

73 several studies, and the structural bases of their wide specificity are now relatively well known

74 (e.g. large groove, multiple binding sites in S1 pocket for different amino acid side chains)

75 (Perona et al. 1997; Tsu et al. 1997). Conversely, up until now, the X-ray structure of crustacean

76 trypsins has been revealed just in the crayfish Astacus leptodactylus (Fodor et al. 2005),

77 although Hehemann et al. (2008) and Perera et al. (2010b) modeled the three-dimensional

78 structure of trypsins from the crab Cancer pagurus and the spiny lobster Panulirus argus,

79 respectively. Nevertheless, the available information on the structure of the different crustacean

80 trypsins (Fodor et al. 2005; Hehemann et al. 2008; Perera et al. 2010b) point to these enzymes

81 sharing the structural elements required for trypsin specificity with their vertebrate counterparts

82 (Perona and Craik 1995; Hedstrom 1996).

83

84 Crustaceans (and invertebrates in general) present several trypsin isoenzymes (Muhlia-Almazán 85 et al. 2008), as also occurs in fish (Rungruangsak-Torrissen 2012). Conversely, the number of 86 trypsin isoenzymes in mammals is reduced: only two trypsins (one cationic and one anionic 87 form) have been reported in humans (Figarella et al. 1975), bovines (Puigserver and Desnuelle 88 1971), pigs (Voytek and Gjessing 1971) and dogs (Ohlsson and Tegner 1973). The lower 89 number of isoforms seems to be correlated to an increase in the complexity within the family of 90 serine-peptidases, with several genes acquiring additional domains other than the trypsin 91 domain (Patthy 1999).

93 Genes coding for trypsin enzymes in crustaceans are arranged into multi-gene families (Klein et 94 al. 1998), leading to several isoforms (Brockerhoff et al. 1970; Galgani and Nagayama 1987; 95 Kim et al. 1992; Klein et al. 1996; Sainz et al. 2004, 2005; Perera et al. 2008a). According to the 96 combination of isoforms in individuals, different trypsin phenotypes have been described in the 97 penaeid shrimp Litopenaeus vannamei (Sainz et al. 2004, 2005) and in the spiny lobster $P$. 98 argus (Perera et al. 2010a). However, to our knowledge, there is no information about the 99 digestive role of trypsin isoforms in decapods, although there is evidence of digestive advantage 100 of certain phenotypes in other crustaceans (Daphnia, Schwarzenberger et al. 2010). However, 101 the physiological impacts of trypsin polymorphism have been found on fish size (Torrissen 102 1987), growth rate (Torrissen 1991; Torrissen et al. 1993), protein utilization (Torrissen et al. 103 1994) and feed efficiency (Torrissen and Shearer 1992; Rungruangsak-Torrissen et al. 1998), as 104 reviewed in Rungruangsak-Torrissen and Male (2000) and Rungruangsak-Torrissen (2012).

105 Examples of the physiological impact of enzyme polymorphism exist for other digestive 106 enzymes such as amylase (Drosophila, Kirpichnikov and Muske 1980; Crassostrea gigas, 107 Prudence et al. 2006; chickens, Hughes et al. 1994). 
109 Two fundamental questions in physiology and evolutionary biology are how genetic differences

110 produce different physiological performances and how fitness is achieved. According to Nelson

111 and Hedgecock (1980), heterozygosity in decapod crustaceans is triggered by a broad food

112 spectrum, thus coining the term 'adaptive polymorphism'. The extremely high heterogeneity of

113 digestive serine-endopeptidases found in the opportunistic predator caridean shrimp Crangon

114 crangon is thought to be an adaptation to the variability of food (Saborowski et al. 2012),

115 although the underlying mechanisms are still not completely understood. During the last years

116 some reviews have been published on crustacean trypsins (Muhlia-Almazán et al. 2008; Carrillo

117 et al. 2008; Sainz and Córdova-Murueta 2009), integrating essential information on their

118 molecular and biochemical properties. However, due to the lack of experimental evidence, some

119 important issues such as the adaptive value of polymorphisms and the regulatory mechanisms

120 behind protein digestion have been poorly assessed in crustaceans. In this review, we use the

121 spiny lobster $P$. argus as a model organism for a deeper advance in the understanding of trypsin

122 polymorphism in crustaceans, by integrating updated molecular, biochemical and ecological

123 information. The present review provides insights into the biochemical basis of the ecological

124 success of P. argus as a top predator in benthic communities of tropical seas (Marx and

125 Herrnkind 1985; Colinas-Sanchez and Briones-Foorzan 1990; Lalana and Ortiz 1991; Herrera et

126 al. 1991; Cox et al. 1997).

127

128 2. First approaches: studies on crude extracts

129

130 The first attempt to characterize trypsin-like enzymes in Panulirus argus was performed by a

131 combination of biochemical assays and casein zymograms performed on crude extracts of the

132 digestive gland and gastric juice of this species (Perera et al. 2008a). The optimal pH for trypsin

133 activity was found to be around 7.0, while the activity remained high over a broad alkaline $\mathrm{pH}$

134 range. The optimal temperature was $60^{\circ} \mathrm{C}$, and the optimal ionic strength was between 100-200

$135 \mathrm{mM} \mathrm{NaCl}$. Enzymes responsible for tryptic activity were stable up to $55^{\circ} \mathrm{C}$ for at least $1 \mathrm{~h}$,

136 although activities were notably affected at $60^{\circ} \mathrm{C}$, and were resistant to moderate acid conditions

137 (i.e. pH 5-6). Similar results have been obtained in other spiny lobster species (Panulirus

138 interruptus, Celis-Guerrero et al. 2004). Lobster trypsins were found to be relatively resistant to

139 autoproteolysis (Perera et al. 2008a, 2010b), as those of shrimp (Sainz and Córdova-Murueta

140 2009) and crabs (Hehemann et al. 2008).

141

142 Trypsin activity dominates over all other proteinase activities in the digestive gland and the

143 gastric juice of $P$. argus (Perera et al. 2008a), which is in agreement with previous reports in 
144 other spiny lobster species (Panulirus japonicus, Galgani and Nagayama 1987; Jasus edwardsii,

145 Johnston 2003; Panulirus interruptus, Celis-Guerrero et al. 2004). Also, as described in other

146 crustaceans (Sainz et al. 2004; Klein et al. 1996) and lobster species (Celis-Guerrero et al.

147 2004), high trypsin activity in P. argus occurs associated with several isoforms of the enzyme

148 (Perera et al. 2008a). Among the five isoforms found in casein zymograms, the three faster

149 bands were the most active (Perera et al. 2008a). In a further study, three different trypsin

150 phenotypes were defined according to the presence of these three main isoenzymes in individual

151 lobsters (Fig. 1) (Perera et al. 2010a). Specimens with the three main isoenzymes were named

152 phenotype A, individuals lacking the isoenzyme of higher electrophoretic mobility were named

153 phenotype $\mathrm{B}$, while lobsters lacking the isoenzyme of middle electrophoretic mobility were

154 named phenotype C (Fig. 1). The trypsin isoform of minor electrophoretic mobility was present

155 in all lobsters analyzed so far in our laboratory. The studied lobster specimens exhibited the

156 following phenotype frequency: A $(41.2 \%)>\mathrm{B}(35.3 \%)>\mathrm{C}(23.5 \%)$. Using the same method

157 (substrate-SDS-PAGE), similar trypsin phenotypes have been described in the shrimp

158 Litopenaeus vannamei (Sainz et al. 2004, 2005; Sainz and Córdova- Murueta 2009). The

159 separation of trypsin isoenzymes from Atlantic salmon by a more resolutive technique,

160 isoelectric focusing on agarose-IEF gel, allowed the identification of a higher number of

161 phenotypes. Three common isoenzymes (TRP-1*100, TRP- $2 * 100$, and TRP-3) were also

162 identified, but with two variants in the TRP-1 system (TRP-1*75, TRP-1*91) and one variant in

163 the TRP-2 system (TRP-2*92) (Torrissen 1987; Rungruangsak-Torrissen and Male 2000;

164 Rungruangsak-Torrissen 2012). The application of isoelectric focusing to lobster or shrimp

165 enzymes would identify more isoenzymes and resultant phenotypes.

166

167 Trypsin phenotype is not affected by dietary treatment, molt cycle, or time, either in shrimp

168 (Sainz et al. 2005) or in the lobster (Perera et al. 2008b), indicating that the regulation of trypsin

169 activity occurs quantitatively by changing the concentration of the different isoforms. It has

170 been postulated that the three main isotrypsins described in shrimp depend on two loci: one

171 homozygous locus yields one isoenzyme and one heterozygous locus yields the other two

172 isoenzymes (Sainz et al. 2005).

173

174 3. Biochemical features of digestive trypsins

175

176 Biochemical characterization of Panulirus argus trypsins was accomplished after purification of

177 the five isoenzymes including the three main isoforms (Perera et al. 2012a). The molecular

178 masses of lobster trypsins range from 35 to $36 \mathrm{kDa}$, being similar to those reported for other

179 crustaceans. All isolated enzymes have restricted trypsin activity (type II brachyurins, Barret et 
180 al. 1998), and show the distinctive trypsin preference for Arg over Lys in the P1 position. As

181 anticipated by studies on crude extracts of the digestive gland and gastric juice of $P$. argus,

182 optimal $\mathrm{pH}$ for most isoforms ranges from 7 to 8 , although one trypsin exhibits maximum

183 activity at $\mathrm{pH}$ 6-6.5, and this same isoenzyme has double the activity of the other isoforms at $\mathrm{pH}$

1845 (Perera et al. 2012a). Additionally, all lobster trypsins require calcium coordination for

185 maximal activity, and most of them need this ion for stability in acidic media (Perera et al.

186 2012a). Interestingly, one of the isoenzymes appears to be fairly resistant to relatively low $\mathrm{pH}$

187 values, irrespective of the presence of calcium. In general, kinetic constants obtained for

188 trypsins in P. argus compare well with those reported for other trypsins. While P. argus trypsins

189 are less efficient than those present in fish (e.g. Engraulis japonicus, Ahsan and Watabe 2001;

190 Oncorhynchus keta, Toyota et al. 2007; Oreochromis niloticus, Unajak et al. 2012) and cold-

191 adapted crustaceans (e.g. Thenus orientalis, Johnston et al. 1995; Euphausia pacifica, Wu et al.

192 2008), they are more efficient than the bovine trypsin (Rascón et al. 2011). All P. argus trypsins

193 have similar $K_{m}$ values $\left(0.08-0.19 \mathrm{mmol} \mathrm{L}^{-1}\right)$ and most of them present similar turnover numbers

194 ( $\left.k_{\text {cat }}: 0.57-1.15 \mathrm{~s}^{-1}\right)$, leading to similar catalytic efficiencies $\left(k_{\mathrm{cat}} / K_{m}: 4.82-6.04 \mathrm{~s}^{-1} \mathrm{mmol} \mathrm{L}^{-1}\right)$.

195 However, the trypsin isoenzyme of middle electrophoretic mobility has a low kcat $\left(0.16 \mathrm{~s}^{-1}\right)$,

196 resulting in the lowest catalytic efficiency $\left(2.02 \mathrm{~s}^{-1} \mathrm{mmol} \mathrm{L}^{-1}\right)$ among isoenzymes (Perera et al.

197 2012a).

198

199 However, what does all this information could mean? While P. argus trypsins share most of the

200 general features of the clan PA, family S1A, including optimal conditions for activity, calcium

201 requirement, effect of inhibitors, and kinetic constants, they slightly differ in some important

202 functional features including catalytic efficiency (Perera et al. 2012a), which likely lead to

203 diverse digestive performances in the living organism. It has been suggested previously in the

204 penaeid shrimp Litopenaeus vannamei that differences in catalytic properties among trypsin

205 isoforms could provide digestive advantages to individuals carrying certain phenotypes (Sainz

206 et al. 2004; Sainz and Córdova-Murueta 2009). Recently, we have provided experimental

207 evidence of advantages in the digestion related to the presence of some isoforms in P. argus.

208 Efficiency in protein digestion is greater in individuals having all three major isoenzymes, while

209 it varies in individuals with other phenotypes depending on the protein substrate (Perera et al.

210 2010a, 2012a).

211

212 Variations in protein digestion related to biochemical properties of the different isoforms were

213 confirmed after purification of $P$. argus isotrypsins, since the isoenzyme of the lowest catalytic

214 efficiency is mainly present in less efficient (according to in vitro digestion studies) individuals

215 (Perera et al. 2012a), although the impact of these variations on growth performance still needs 
216 to be tested. There are few but consistent examples of advantages related to the presence of

217 some digestive isoenzymes in other organisms, such as amylase in Drosophila (Kirpichnikov

218 and Muske 1980), Crassostrea gigas (Prudence et al. 2006) and chickens (Hughes et al. 1994),

219 or trypsins in Salmo salar (Rungruangsak-Torrissen and Male 2000; Rungruangsak-Torrissen

220 2012) and Daphnia (Schwarzenberger et al. 2010), which in most cases are beneficial rewards

221 for growth to individuals with certain genotypes. The best studied case is Atlantic salmon, in

222 which increased growth rate in fish possessing the trypsin isoform TRP-2*92 (Torrissen 1987,

223 1991) is due to better food conversion and protein efficiency (Rungruangsak-Torrissen et al.

224 1998). While initial attempt to explain these differences in fish by protein in vivo digestibility

225 studies failed probably due to poor sensitivity of the chromic oxide method (Torrissen and

226 Shearer 1992), a further study using a more sensitive in vitro method demonstrated differences

227 in digestion ability among isoenzymes (Bassompierre et al. 1998). However, there are

228 indications that major effect of the variant TRP-2*92 is postabsorptive promoted by higher and

229 faster postprandial free amino acid in plasma which stimulate higher secretion of plasma insulin

230 leading to stimulation of protein synthesis in white muscle (Rungruangsak-Torrissen 2012).

231

232 It is known that gene duplication followed by sequence divergence provided a mechanism for

233 the evolution of isoenzymes and eventually new functional properties (Taylor and Raes 2004).

234 Although the structural features of $P$. argus isotrypsins responsible for their functional variation

235 remain largely unknown, recent molecular studies on $P$. argus trypsins have provided insights

236 on the enzyme regions that may account for this variation (Perera et al. 2012a; Perera et al.

237 2010b).

238

239

\section{Molecular characterization of digestive trypsins}

240

241 Several transcripts of 870-875 bp of total length and 798-802 bp of open reading frame for 242 anionic trypsins were identified in the digestive gland of Panulirus argus (PaTryla, PaTrylb,

243 PaTry2, PaTry3 and PaTry4 with GenBank accession numbers GU338026, GU338027,

244 GU338028, GU338029 and GU338030 respectively) (Perera et al. 2010b). According to their

245 nucleotide variation, these transcripts were suggested to belong to three different gene families

246 (Perera et al. 2010b), as in the shrimp Litopenaeus vannamei (Klein et al. 1996), although

247 definitive genomic studies are needed in P. argus. The predicted proteins for these transcripts

248 have the signal and activation peptides well conserved among crustacean trypsins, with the

249 exception of the parasite copepod Lepeophtheirus salmonis (Johnson et al. 2002), indicating that

250 there are few differences in the secretion and activation mechanisms of these enzymes. The

251 residues of the catalytic triad His74, Asp125 and Ser218 (equivalent to His57, Asp102 and Ser 
252195 in chymotrypsin nomenclature) are conserved across all studied $P$. argus trypsins, as well

253 as residues conferring trypsin specificity (Perera et al. 2010b), which indicates these are active

254 enzymes.

256 Three-dimensional (3D) homology models were obtained for all $P$. argus deduced trypsins. The 257 model data for PaTryla, PaTrylb, PaTry2, PaTry3 and PaTry4 are available in the PMDB 258 database under the accession numbers PM0076235, PM0076234, PM0076233, PM0076232 and 259 PM0076231, respectively. All P. argus trypsins (e.g. PaTry3, Fig. 2a) showed the conserved 260 core structure of the chymotrypsin fold, consisting of two six-stranded $\beta$-barrel domains packed 261 against each other, with the catalytic residues located at the junction of the two barrels (Perera et 262 al. 2010b). These 3D models also anticipate all other structural features of trypsins (i.e. disulfide 263 bonds, superficial loops, calcium-binding site, the configuration of the active centre and the 264 enzyme pocket), with no major difference among lobster isoenzymes (Perera et al. 2010b).

265 Considering the importance of the 3D structure in the functionality of enzymes, it is not 266 surprising the presence of a well conserved architecture in lobster trypsins. However, when 267 lobster trypsins were compared to crayfish trypsin (Fodor et al. 2005) structural differences 268 were noticed, especially in the surface loops. Variation in these regions, which are not core 269 elements of the fold, but important for inhibitors/substrate binding (Fodor et al. 2005), may be a 270 way for evolutionary adaptation (Perona and Craik 1997). In insects, surface loops notably vary 271 among isoenzymes even within the same species, and this is suggested to be related to the 272 presence of proteinase inhibitors in the diet (Díaz-Mendoza et al. 2005). Both the high number 273 of gene copies and the high degree of polymorphism found in crustacean trypsins (Klein et al. 274 1998) point to a huge source of variation for adaptive evolution to occur in species differing in 275 feeding habits (e.g. crayfish and spiny lobster). On the other hand, despite the low intra-specific 276 variation in overall 3D structure of $P$. argus trypsins, amino acid substitutions occur among 277 isoforms (Perera et al. 2010b), these being presumably the structural basis of the observed 278 intra-specific differences in catalytic efficiencies. Insights into the possible effect of these point 279 variations among isoforms arise from an evolutionary assessment of lobster trypsin sequences 280 (see next section).

282 Unfortunately, transcripts and isoenzyme in lobster have been not matched due to high sequence 283 similarity (Perera et al. 2010b) and difficulties for isolating high amount of the isoenzymes 284 (Perera et al. 2012a). To circumvent these drawbacks we made an attempt to identify, at least 285 indirectly, the isoenzymes in $P$. argus. We selected individuals lacking some particular 286 isoenzyme in casein zymograms and used them for RT-qPCR analysis using specific primers for 287 the most abundant transcripts: PaTryla, PaTry2, and PaTry3. We found that all lobsters highly 
express PaTry3. This transcript should correspond to the isoenzyme of minor electrophoretic mobility since this form of the enzyme is always present in zymograms. On the other hand, we

290 observed that lobsters that lack the isoenzyme of higher electrophoretic mobility in zymograms

291 exhibit very low or no expression of PaTryla, and the same occurred with PaTry2 in lobsters without the isoenzyme of middle electrophoretic mobility (Fig. 3).

\section{Approach to the evolution of trypsins in lobster}

The assessment of the ratio of non-synonymous to synonymous substitution $(\mathrm{Ka} / K \mathrm{~s})$ (Hurst 2002) in lobster trypsins has provided some insights into the evolution of these isoenzymes (Perera et al. 2012b). Nucleotide synonymous substitutions do not change amino acids in a protein and generally have neutral evolutionary effects, while non-synonymous mutations result

300 in amino acid substitutions and occur more often under selective pressure (Hurst 2002).

301 Calculated $K \mathrm{a} / \mathrm{Ks}$ suggested that isoenzymes in lobsters are under purified or neutral selection

302 (Perera et al. 2012b). It is well known that enzymes are subjected to functional constraints, thus

303 the result was somewhat expected. However, because averaging $\mathrm{Ka} / K \mathrm{~s}$ for all sites does not

304 consider the type of selective pressure applied to individual amino acids, maximum likelihood

305 approach was later used for detecting positively evolving sites in a background of

306 purifying/neutral selection. According to this strategy, several positively evolving sites (25

307 codons) were found in P. argus trypsins (Perera et al. 2012b). It is interesting to remark that not

308 all trypsin isoenzymes appear to have been under positive selection at these sites, since $72 \%$ of

309 the positive selected sites imply unique substitutions in one particular transcript, PaTry3 (Perera

310 et al. 2012b). Unequal patterns of molecular evolution for different trypsin isoenzymes have

311 been reported before in other invertebrates (e.g. Drosophila, Wang et al. 1999).

313 Positive selection may be an important force driving adaptive evolution (Wu et al. 2009), but

314 trypsin isoenzyme sequences from other spiny lobster species are required to truly determine

315 whether some trypsins are evolving under selective pressure at certain sites to undergo adaptive

316 evolution. It is noteworthy that 55\% of all positively evolving sites in P. argus PaTry3 are

317 within (or in close vicinity to) functionally relevant motifs, like surface loops as well as the

318 calcium binding site (Perera et al. 2012b), supporting the hypothesis that trypsin polymorphism

319 in $P$. argus may be non-neutral and, thus, have an adaptive value in relation to feeding. These

320 regions are known to be the most susceptible to variation through trypsin evolution (Rypniewski 321 et al. 1994). 
323 The role of interaction with environmental factors in lobster trypsins evolution is also supported

324 by analysis of the 3D structures (Perera et al. 2010b) and mapping of the positively selected

325 residues to these structures in relation with proteinase inhibitors (Fig. 2b). Canonical inhibitors

326 are known to bind the enzymes in a substrate-like fashion and thus, are suited for the study of

327 possible interactions with proteinaceous substrates. A cluster of aromatic residues (mostly Phe)

328 in Loop37 of the crayfish Astacus leptodactylus trypsin forms the binding surface for positions

329 P4'- P5' of the C-terminal of the trypsin inhibitor from desert locust Schistocerca gregaria

330 (SGTI), and might play a role in the orientation of the inhibitor (Fodor et al. 2005). This

331 hydrophobic loop of the crayfish trypsin plays a similar role during the interaction with bovine

332 pancreatic trypsin inhibitor (BPTI) (Molnár et al. 2013). In the lobster, these hydrophobic

333 residues are conserved (Fig. 2b), but there are two additional and positive selected Phe residues

334 in the distal part of loop 37 of PaTry3 isoform. Given the role of hydrophobic residues in this

335 loop, these two positive selected residues may be involved in more extended interactions with

336 dietary substrates (Fig. 2b). The two positive selected sites found in trypsin-like serine proteases

337 in the malaria mosquito Anopheles gambiae are also located at the surface, in regions that

338 contact proteinaceous substrates (Wu et al. 2009). A positive selected residue in PaTry3 calcium

339 binding loop may favors a stronger calcium binding (Perera et al. 2012b). Besides positive

340 selected residues in lobster trypsins probably contacting the substrate (Fig. 2b) or the calcium

341 ion, others lie in important regions for activity, like those in loops 1, 2, and 3 (Perera et al.

342 2012b). Since these other substitutions are in the neighborhood of primary or secondary

343 specificity determinants in these loops, an effect on the function of the enzyme cannot be ruled

344 out. Some residues in these surface loops of trypsins may ensure the optimal positioning of key

345 residues or stabilize the geometry of the enzyme (Rypniewski et al. 1994). Adaptive evolution

346 in lobster trypsin may have occurred on both substrate binding and activity. Trypsins from

347 different insects differ in the strength with which their subsites bind the substrate or the

348 transition state (Marana et al. 2002).

349

350 Trypsin diversity is particularly high in insects, decapod crustaceans, and fishes. The

351 phylogenetic relationship of a selected group of trypsin isoenzymes from these three groups is

352 shown in Fig. 4. In general, most trypsin isoforms trend to group in accordance with the

353 phylogenetic relationships of species, although crustacean trypsins clustered with vertebrate

354 trypsin and not with those of the other Arthropod group analyzed. It is accepted that members of

355 multigene families do not usually evolve independently, so greater sequence similarity is

356 commonly found within a species than between species (between paralogues than between

357 orthologues) (Liao 1999). However, as in Lepidoptera (Lopes et al. 2004), mosquito (Wu et al.

358 2009), and P. argus (Perera et al. 2012b), some degree of independent evolution for particular 
trypsin isoenzymes may occur in other crustaceans, since the topology of phylogenetic tree of

360 related species (e.g. penaeid shrimp) reflects relationships among some trypsin variants rather

361 than among species (Perera et al. 2010b) (Fig. 4). Thus, some trypsins isoform in crustaceans

362 may have escaped from homogenization of DNA sequences (i.e. concerted evolution, Liao

363 1999), as demonstrated to occur in Drosophila (Wang et al. 1999), to undergo adaptive

364 diversification.

366 Trypsin diversification is less understood in terms of functionality in crustaceans respect to

367 insects and fishes. Major diversification occurs in insects, with the highest amino acid sequence

368 identity shared by two putative trypsins in some species being just $61.3 \%$ (Chen et al. 2013).

369 The occurrence of multiple isoforms is thought to provide an adaptive advantage for insects

370 feeding on plants containing inhibitors, although the effects of small variations in amino acid

371 sequences on enzyme activity and sensitivity to inhibitors are still unclear (Srinivasan et al.

372 2006; Spit et al. 2014). Functional properties of enzymes cannot be predicted based only on

373 sequences, and experimental data are needed to afford true evidence of functional

374 diversification (Srinivasan et al. 2006). However, conventional purification methods have

375 limited resolution in dealing with protease isoforms, expression in heterologous systems faces

376 problems such as toxicity of the expressed protease and misfolding of the recombinant

377 polypeptide, and minor changes in activity may not be detectable with synthetic substrates

378 (Srinivasan et al. 2006). In few insect groups such as Lepidoptera (Lopes et al. 2004) and

379 mosquito (Soares et al. 2011) transcripts have been matched with the enzyme, but major

380 evidences for functional diversification were found for lepidopteran trypsins (Lopes et al. 2004).

381 Comparing inhibitor-sensitive and insensitive lepidopteran trypsins, several residues have been

382 proposed as critical for trypsin resistance to plant inhibitors, resulting in increased inhibitor

383 hydrolysis (preference for lysine at the $\mathrm{P} 1$ position), and decreased binding to inhibitor

384 hydrophilic reactive sites (substrate binding subsites more hydrophobic than trypsins from

385 insects in other orders) (Lopes et al. 2004). The topology of general feeder lepidopteran trypsins

386 in Fig. 4 indicates sequence divergence between sensitive and insensitive trypsins (Lopes et al.

387 2004). Specialist feeders Lepidoptera such as Manduca sexta exhibit less enzyme diversification

388 than general feeders (Srinivasan et al. 2006) (Fig. 4). In Drosophila melanogaster, trypsin

389 isoforms are known exhibit different pattern of evolution: two genes are evolving in concert

390 (gamma and delta trypsin genes), a third gene appears to be evolving independently (epsilon

391 trypsin gene), and the remaining two genes show an intermediate pattern (Wang et al. 1999)

392 (Fig. 4). In fishes, trypsins are separated in two major clusters (Psochiou et al. 2007). The first

393 one gathered trypsinogens of fish species adapted to extreme cold environments, and the second

394 cluster grouped all other fish trypsinogens (Psochiou et al. 2007) (Fig. 4). 
396 The trypsin isoform of lobster with minor electrophoretic mobility in Fig. 1 is present in all $P$.

397 argus individuals (Perera et al. 2008a, 2010a), is the most reactive toward native protein

398 substrates (Perera et al. 2012a), and its transcript was indirectly identified as PaTry3, for which

399 some positive selected sited were found (Perera et al 2012b). Forces driving diversification (e.g.

400 diet features, environmental temperature) of crustacean trypsins and structural changes involved

401 need further evaluation.

402

403 6. Positive correlation between apparent adaptive evolution and expression rate

404

405 Several factors are known to be involved in the regulation of transcription in eukaryotes

406 (Brivanlou and Darnell 2002) and many genome regions that interact with these factors have

407 been also identified (Nègre et al. 2001), usually in (Cis) 5' regions (Wray et al. 2003).

408 Unfortunately, there is no information on the genomic sequence of trypsin isoenzymes of

409 lobster and, therefore, neither on genomic regulatory elements. In the copepod Lepeophtheirus

410 salmonis, several candidate promoter sequences have been identified in association with trypsin

411 genes (Kvamme et al. 2005), but in general the information on this issue is scarce in crustaceans

412 in comparison to insects (Xiong and Jacobs-Lorena 1995; Mazumdar-Leighton and Broadway

413 2001). Trypsin isoenzymes in Panulirus argus greatly differ in expression rates both in fasting

414 individuals and during feeding (Perera et al. 2010b, 2012b), thus they constitute a suitable

415 model for studying the regulation of gene expression in crustaceans.

416

417 The transcript for which positive selected sites were detected is by far the most expressed in the 418 digestive gland of P. argus (Perera et al. 2012b). More interestingly, it is the only transcript for 419 which dietary up-regulation could be demonstrated, while all other trypsin isoforms appear to be 420 expressed in a constitutive fashion (Perera et al. 2012b). This result also supports the suggestion 421 that isoenzyme variation in lobster arose as a result of adaptive evolution to increase fitness 422 (Perera et al. 2012b). Although the transcriptional regulation of crustacean trypsins by dietary 423 proteins was reported before (Le Moullac et al. 1996; Muhlia-Almazán et al. 2003), this is the 424 first demonstration of a differenced response in expression of trypsin isoforms to dietary 425 proteins for a crustacean species. However, this is not the first time that differences in response 426 to diet occur among isoforms of digestive enzymes in invertebrates. In the oyster Crassostrea 427 gigas, one amylase gene is regulated at the mRNA level when food varied quantitatively, 428 whereas the other gene present is either not regulated under these conditions or it is expressed at 429 low mRNA levels (Huvet et al. 2003, 2008). While positive correlation between apparent 430 adaptive evolution and expression rate is likely to occur in P. argus isotrypsins, more studies are 
needed to confirm this hypothesis. It is known that high expression levels usually correlate with

432 low rates of protein evolution (Drummond et al. 2005; Larracuente et al. 2008). However, some

433 works have provided evidence of concomitant adaptive evolution in highly expressed genes of

434 the Drosophila genome (Holloway et al. 2007), and trypsin-like genes in mosquito with

435 increased expression after meal (Wu et al. 2009).

436

\section{Trypsins isoenzymes and physiological needs}

439 As key enzymes in protein digestion, gene expression and, more important, activity of trypsins

440 in lobster should be related with the amino acid needs for energy and growth. Variations of

441 trypsin activity in spiny lobsters are developmentally clued (Jasus edwardsii, Johnston 2003;

442 Panulirus argus, Perera et al. 2008b) and could reflect changing physiological requirements as

443 lobsters grow, but the meaning of these variations is not clear because few studies are still

444 available. Johnston (2003) found a positive relationship between total trypsin activity and size

445 in the spiny lobster $J . e d w a r d s i i$, coinciding with an increase in size of the digestive gland, but

446 not a similar trend with specific activity. In contrast, trypsin specific activities tend to increase

447 with age in P. argus, although the increase in size only accounted for $68 \%$ of the variation

448 (Perera et al. 2008b). Further studies are necessary in order to understand how variations of

449 trypsin activity in lobsters of different size correlate with their physiological needs, and

450 particularly the role of trypsin isoforms.

452 In thoroughly studied fish such as Atlantic salmon, the trypsin isoenzyme composition have 453 been shown to affect absorption and transport of free amino acids (FAA), including the ratio of 454 essential to non-essential FAA (Torrissen et al. 1994; Rungruangsak-Torrissen and Male 2000; 455 Rungruangsak-Torrissen 2012). Higher protein digestion and FAA absorption in fish carrying 456 certain trypsin phenotypes produce a higher rate of protein synthesis in white muscle in 457 association with higher secretion of plasma insulin (Rungruangsak-Torrissen et al. 1999;

458 Rungruangsak-Torrissen and Male 2000; Rungruangsak-Torrissen 2012). These studies in fish 459 may provide guidance for future studies in crustaceans, although differences are expected to 460 occur (e.g. endocrine factors). Also, studies in salmon fish have indicated that digestive

461 efficiency and growth are not always related with trypsin specific activity, but with the activity 462 ratio of trypsin to chymotrypsin (T/C ratio) (Rungruangsak-Torrissen 2012).

463

464 Since the molt cycle drives extensive physiological changes in crustaceans, it constitutes a good 465 model for assessing the physiological meaning of variations in digestive enzymes (Perera et al. 466 2008b). Whereas changes in digestive enzymes during the molt cycle were studied in different 
468 Gimenez et al. 2001, 2002), there is just one study in spiny lobsters (Perera et al. 2008b).

469 Variations in the activity of trypsins and other digestive enzymes in P. argus (Perera et al.

470 2008b) resemble the foraging and feeding patterns observed in previous studies (Lipcius and

471 Herrnkind 1982), showing a gradual increment during intermolt to highest levels at late

472 intermolt and early premolt (when requirements of proteins are high for energy and growth),

473 and then a gradual decrease to minimal activity at late premolt and postmolt (when lobsters do

474 not eat and use the energy stored as lipids and glycogen). In a recent study on the blue

475 swimming crab, Portunus pelagicus, variations in T/C ratio were found to match with expected

476 growth rate through the molt cycle (Rungruangsak-Torrissen 2012), similar to the observations

477 on fish mentioned above. However, the validation of $\mathrm{T} / \mathrm{C}$ ratio as feed efficiency indicator in

478 crustacea needs further studies. No discernible patter of T/C ratio during the mol cycle can be

479 drowning from data of trypsins and chymotrypsin activity in the digestive gland of the lobster $P$.

480 argus (Perera et al. 2008b), despite variation of both trypsin and chymotrypsin activity are

481 rather similar in the lobster (Perera et al. 2008b) and the blue swimming crab (Rungruangsak-

482 Torrissen 2012). In addition, a substantial share of proteolytic activity in some crustaceans such

483 as carideans is caused by cysteine proteinases, instead of trypsin or chymotrypsin enzymes

484 (Teschke and Saborowski 2005). Enzyme activity variations should be under genetic and

485 hormonal control, but also appearing to be closely regulated by feeding.

486

487 8. Trypsin regulation and feeding

488

489 From early studies it is known that new digestive enzyme produced in the digestive gland of

490 crustaceans are subsequently discharged into the gland lumen and then accumulated (i.e.

491 extracellular storage) in its active form in the cardiac stomach (Vogt et al. 1989). Studies in

492 lobster (Perera et al. 2008a; Simon 2009; Perera et al. 2012b) and other crustaceans have

493 regularly reported high trypsin activity in the gastric fluid of unfed animals. However, despite

494 crustacean zymogen granules differ from that of vertebrates (Vogt et al. 1989), both the deduced

495 cDNA sequence (i.e presence of trypsinogen activation peptide) of several crustacean trypsins

496 (Muhlia-Almazán et al. 2008) including P. argus (Perera et al. 2010), and immunohistology

497 studies (Sainz et al. 2004) support that trypsins are also stored as inactive zymogen in

498 crustaceans to be secreted after feeding. Significant amount of trypsins enzymes are secreted by

499 lobster after feeding with maximal activity in gastric fluid attained four hours after ingestion

500 (Simon 2009; Perera et al. 2012b). Likewise, in continuous digester insects (e.g. Lepidoptera

501 and Diptera larvae) feeding stimulates secretion, but enzymes are released continuously at a

502 basal rate in unfed animals (Woodring et al. 2009). That is why trypsin and other digestive 
enzymes are always present in the gut lumen of continuous digesters insects, while in batch

504 digesters such as mosquitoes trypsin is not present in the unfed insect (Lehane et al. 1995). In

505 mosquito, trypsin is not stored in the epithelial cells as an inactive enzyme, but is synthesized,

506 activated and released into the gut lumen after the blood meal (Borovsky 2003). In humans and

507 other higher vertebrates, trypsins are synthesized, often stored for a long time, and then secreted

508 as inactive zymogens, which are normally activated only upon entry into the duodenum (van

509 Acker et al. 2006). In mammalian pancreatic cells, the pancreatic secretory trypsin inhibitor

510 (PSTI) prevents the premature activation of trypsin and other digestive enzymes (Hirota et al.

511 2006). In several insect species protease inhibitors that structurally resemble the mammalian

512 PSTI have been predicted in silico, and a PSTI-like protein from the African migratory locust,

513 Locusta migratoria, was cloned, sequenced, and demonstrated to be involved in controlling

514 proteolytic activity (van Hoef et al. 2011). These results in insects point to the existence of an

515 ancient protective mechanism in metazoan digestive systems (van Hoef et al. 2011). Protease

516 inhibitors have been described in the digestive gland of some crustaceans (de Albuquerquee-

517 Cavalcanti et al. 2002) but their role is still unknown.

518

519 While regulatory mechanisms behind protein digestion in crustaceans remain fairly unknown, a

520 recent study has provided evidence of dietary regulation of trypsin enzymes in P. argus (Perera

521 et al. 2012b). Experimental evidence leads us to propose that trypsin enzymes in P. argus are

522 regulated at the transcription and secretion level by the quality of dietary proteins, through two

523 distinct signaling pathways. Intact proteins rather than protein hydrolysates stimulate trypsin

524 secretion in the lobster (Fig. 5), while the signal for differential isotrypsin transcription seems to

525 be the appearance of small peptides or free amino acids (i.e. protein digestion end-products) in

526 the digestive gland (Fig. 5). These facts support a model of stepwise regulation of trypsin

527 enzymes in lobsters during digestion (Perera et al. 2012b). While just the removal of gastric

528 fluid is known to stimulate secretion in some crustaceans (Vogt et al. 1989), a regulatory

529 mechanisms for trypsin secretion by dietary proteins should have evolved early during

530 evolution, as trypsin secretion is also more stimulated by intact proteins in very distant groups

531 like insects (Blakemore et al. 1995; Lehane et al. 1995; Graf et al. 1998; Noriega and Wells

532 1999) [although contradictory results have been obtained in some species (Woodring et al.

533 2009)], fishes (Cahu et al. 2004; Koven et al. 2002) and rats (Green and Miyasaka 1983;

534 Owyang 1994). Such a general mechanism for regulating trypsin secretion may be related to the

535 fact that intact proteins in the digestive tract always mean recent food ingestion.

536

537 Mechanisms controlling trypsin secretion are relatively well known in vertebrates. Feedback

538 inhibition of pancreatic enzyme secretion is mediated by trypsin and other proteases in the 
539 intestine in rat, chickens, pigs and humans by means of the trypsin-sensitive cholecystokinin-

540 releasing peptide. Intact dietary protein in the intestine competes for the trypsin that would

541 otherwise inactivate the factor (Owyang 1994). The resulting increase of cholecystokinin-

542 releasing peptide releases cholecystokinin (CCK) and stimulates pancreatic enzyme secretion

543 (Owyang 1994). Results in rat indicate that the effect of trypsin inhibitor SBTI, which often

544 stimulate secretion, acts by a mechanism not involved in masking (i.e. inhibiting) trypsin

545 activity but acting as a protein, since a non-peptidic trypsin inhibitor did not induce secretion

546 (Hira et al. 1997). Although the action mechanism is not so well understood as in mammals,

547 humoral CCK is also recognized as major regulator of trypsin secretion in fishes (Kofuji et al.

548 2007; Einarsson et al. 1997; Buddington and Krogdahl 2004; Jönsson et al. 2006; Zambonino-

549 Infante and Cahu 2007), regulated by the trypsin-sensitive cholecystokinin-releasing peptide

550 (Zambonino-Infante and Cahu 2007; Tillner et al. 2013).

551

552 However, amino acids and peptides are more effective than intact proteins in stimulating

553 pancreatic exocrine secretion in dogs (Meyer and Kelly 1976) and humans (Thimister et al.

554 1996). Actually, digestion of protein is required to stimulate plasma cholecystokinin (CCK)

555 release, gallbladder emptying, and pancreatic enzyme secretion in humans, while undigested

556 protein is only a weak stimulus to pancreas (Thimister et al. 1996). It is though that under un-

557 stimulated conditions, the feedback regulation between pancreatic enzyme secretion and

558 protease activity in the lumen of the small intestine is operative also in humans, but that in

559 contrast with rats, protease-dependent feedback regulation of pancreatic exocrine secretion in

560 humans is probably not mediated by humoral CCK. In humans and dogs the major pathways of

561 CCK action appear not to be endocrine but neural, involving the sensory receptors at afferent

562 nerves and long vagovagal or short enteropancreatic reflexes (Konturek et al. 2003), although

563 there are difference in the contribution of the different pathways between low and high loads of

564 amino acids (and fatty acids) (Singer 1987). Other hypothesis is that CCK-mediated feedback

565 control of pancreaticobiliary secretion in humans is principally regulated by bile acid

566 sequestration and not by protease activity. There are strong evidences for the presence of CCK-

567 like peptides in crustaceans (van Wormhoudt et al. 1989; Favrel et al. 1991; Resch-Sedlmeier

568 and Sedlmeier 1999; Ravallec-Plé and van Wormhoudt 2003; Ma et al. 2009) but their role on

569 digestive enzyme secretion has been not clarified (Staljanssens et al. 2011).

570

571 Studies in crustaceans have indicated that regulation of trypsin activity occurs also at the

572 transcription level (Klein et al. 1996). Up-regulation of trypsin expression in P. argus by protein

573 digestion end-products (Perera et al. 2012b) appears to be related with the preparation for next

574 feeding (Fig. 5), and matches with the periodic feeding habits of spiny lobsters. Lack of stimuli 
575 (low concentration of digestion end-products) for synthesis of new trypsin enzymes (Perera et

576 al. 2012b) may be related with low amount/activity during fasting periods such as late premolt

577 and postmolt (Perera et al. 2008b). This transcriptional induction of some trypsin isoform in the

578 lobster resemble that occurs in mosquito, where partially digested proteins and peptides released

579 during the earlier part of the digestive cycle, affect the transcription of the late trypsin (see

580 below). Differential expression of trypsin isoforms have been also observed in other insects

581 after feeding different plants (Srinivasan et al. 2006; Chen et al. 2013) although the exact nature

582 of the signaling mechanism is not well understood (Srinivasan et al. 2006). In mammals,

583 transcriptional differences among trypsin isoenzymes have been also reported. Three of the four

584 rat trypsinogen mRNA studied by Hara et al. (2000) increased in response to casein level in

585 diet, while only one reacted to CCK administration.

586

587 There are also repots on regulation of trypsin and other digestive enzymes at the translation

588 level or at both transcription and translation. In the female mosquito trypsin expression is

589 biphasic: an early phase that is translationally regulated, and a late phase that is transcriptionally

590 regulated. Transcription of the early trypsin gene occurs after mosquito female emergence under

591 the control of juvenile hormone, but the transcript remains untranslated before blood feeding

592 (Noriega and Wells 1999). Early trypsin appeared in the mosquito midgut after the blood meal

593 (Noriega and Wells 1999) and its synthesis appears regulated by soluble proteins of variable

594 molecular weights (Borovsky 2003) and the size of the free amino acid pool in the midgut

595 (Noriega et al. 1999) by the Target of Rapamycin (TOR) signaling pathway (Brandon et al.

596 2008). Unlike early trypsin, the transcription of the late trypsin gene is regulated by

597 uncharacterized proteolysis products (Noriega and Wells 1999), probably small peptides

598 (Borovsky 2003). The termination of trypsin biosynthesis, at the translation level, is controlled

599 by the trypsin modulating oostatic factor (TMOF) secreted by the mosquito ovary several hours

600 after feeding (Borovsky 2003). In other hematophagous insects such as Stomoxys calcitrans,

601 increased synthesis of trypsin following the blood meal appears to be regulated also at the

602 translational level (Moffatt et al. 1995). Amino acids also stimulate the synthesis of digestive

603 enzymes at the translational level in rats (Bragado et al. 1998; Sans and Williams, 2002). A

604 study demonstrated that branched-chain amino acids (leucine, isoleucine, and valine), and most

605 notable leucine, stimulate translation initiation in mouse pancreas independent of CCK,

606 although amino acids by themselves are not sufficient for increasing protein synthesis (Sans et

607 al. 2006). Amino acids "prime" the mouse pancreatic translational machinery for protein

608 translation to occur, but a hormonal and/or cholinergic stimulus would be required for a

609 complete stimulation of protein synthesis (Sans et al. 2006).

610 
611 The high degree of polymorphism (Perera et al. 2008a), the marked differences in expression

612 rates (Perera et al. 2010b), and the differences in activity among isoforms (Perera et al. 2012a),

613 provide several points at which regulation of digestive trypsins may occur in P. argus. Our

614 result on the signals inducing transcription and secretion of trypsin isoforms in lobster provide

615 the first evidence of these mechanisms in crustaceans, but they are far to be well understood as

616 in insects or higher vertebrates. The regulation of trypsin and other digestive enzymes in

617 crustaceans by feed is an area that deserves further studies. Besides contributing to understand

618 the evolution of these mechanisms, it has practical implications on the optimization of

619 aquafeeds. There have been contradictory results on the effect of protein hydrolysates on both

620 fish and crustacean growth. High inclusion of protein hydrolysate in diets depressed growth in

621 fishes (Zambonino-Infante and Cahu 2007) and crustaceans (Córdova-Murueta and García-

622 Carreño 2002), while moderate levels have positive effects in fish (Zambonino-Infante and

623 Cahu 2007; Savoie et al. 2011), crustaceans (Córdova-Murueta and García-Carreño 2002), and

624 other invertebrate taxa such as cephalopods (Aguila et al. 2007). Squid meal, which is rich in

625 peptides and small molecular weight proteins (Córdova-Murueta and García-Carreño 2002;

626 Perera et al. 2010a) also promote better growth rates in crustaceans at low supplementation

627 levels (Córdova-Murueta and García-Carreño 2002). Conversely, high levels of krill

628 hydrolysates still enhance growth in shrimps (Córdova-Murueta and García-Carreño 2002) and

629 spiny lobsters (Smith et al. 2005; Barclay et al. 2006). These feed components may exert

630 different effect on the expression, synthesis and secretion of digestive enzymes in the different

631 groups, although more general effects on overall metabolism cannot be ruled out.

632

633 9. Trypsin and feeding ecology

634

\section{9.1. Features of natural diet}

636

637 Little is known on the natural feeding of Panulirus argus larvae (phyllosoma) although it is

638 accepted that, in general, spiny lobster are carnivorous throughout their entire larval cycle

639 (Kittaka 1997). Pelagic phyllosoma from different palinurids have been successfully reared in

640 laboratory on a diet of Artemia and other seafood (Kittaka 1997). A recent assessment of DNA

641 material in the digestive tract of larvae provided indication of salps, cnetophores, and medusae

642 as main zooplankton dietary items in some species (Chow et al. 2011), with preference for some

643 prey items (e.g. chaetognaths) (Saunders et al. 2012). It is known that pelagic zooplankton

644 generally has higher protein and lipid and lower carbohydrate contents than phytoplankton (Le

645 Vay et al. 2001).

646 
647 Shortly after settlement, early Panulirus argus juveniles feed on a wide variety of small and

648 relatively soft invertebrates, mostly mollusks and crustaceans (Marx and Herrnkind 1985;

649 Lalana and Ortiz 1991), and gradually change into bigger size preys (Lalana and Ortiz 1991).

650 The diet of older juveniles remains similar, but there is an increase in prey size and armor

651 (Herrera et al. 1991). The proportions of prey types in the diet of P. argus juveniles vary

652 according to their abundance in the environment (Colinas-Sanchez and Briones-Foorzan 1990;

653 Herrera et al. 1991; Cox et al. 1997). Chemical composition of the natural diet in juvenile and

654 adult spiny lobsters is thought to have a high protein, low lipid and moderate carbohydrate

655 contents (Williams 2007).

656

657 As outlined above, spiny lobsters eat a diverse assemblage of zooplankton species during larval

658 stages and a wide variety of benthic and infaunal invertebrates during juvenile and adult stages.

659 Although the natural diet of spiny lobsters is hence very diverse, it presents two common

660 features: i) high protein content, and ii) wide variation in protein quality. Less variation in

661 quality is expected for dietary carbohydrates and lipids. Glycogen is likely to be the main

662 dietary carbohydrate in lobster diet (Hickman and Illingworth 1980), and triacylglycerols and

663 phospholipids are the main lipids in prey items, probably with a balanced content of all fatty

664 acid families (Zlatanos et al. 2009). Therefore, it is feasible that the ecological success of

665 lobsters relies to a great extent in their capacity to efficiently digest a wide variety of dietary

666 proteins, a process that largely relies on trypsin enzymes (Perera et al. 2008a, 2010a).

667

668

\subsection{Trypsins and natural diet}

669

670 Enzyme activities in decapod larvae reflect adaptations to the trophic levels utilized according

671 to a general pattern. Herbivorous larvae adapt to low energy food by high daily ingestion rates,

672 high enzyme activities, rapid food turnover, and low assimilation efficiency, while carnivorous

673 larvae (which rely upon high-energy digestible preys) exhibit low levels of enzyme activity and

674 longer gut retention times to maximize assimilation efficiency (Le Vay et al. 2001). Trypsins

675 are the major proteases in the digestive system of most decapod crustaceans, and a relationship

676 between trypsin activity and trophic level has been established according to this model in larvae

677 from different decapods (Le Vay et al. 2001), including spiny lobsters (Jones et al. 1997).

678 Carnivorous lobster larvae show comparatively low trypsin activity at first feeding respect to

679 herbivorous penaeid and brachyuran larval stages (Jones et al. 1997). Trypsin activity, however,

680 increased during spiny lobster larval development reflecting enlarges in their digestive capacity

681 (Johnston et al. 2004), a trend that continues in adult stages (Johnston 2003; Perera et al.

682 2008b). 
684 Whereas adult stages of phytoplankton feeder decapods seem to fit to the abovementioned

685 model (Johnston and Freeman 2005), there is another pattern well supported by studies in adult

686 crustaceans. Carnivorous species exhibit a wide range and high activity of proteolytic enzymes,

687 whereas herbivores and omnivores possess highly active carbohydrases. In crabs, key enzymes

688 present in the gut are generally consistent with this other pattern (Johnston and Freeman 2005),

689 and high trypsin activity has been regularly reported in spiny lobster juveniles and adults

690 (Johnston 2003; Celis-Guerrero et al. 2004; Perera et al. 2008a, 2010a, 2012b; Simon 2009).

691 However, there are some contradictory observations in which omnivores, or even herbivorous

692 species, have higher protease activity than predator crustaceans (Johnston and Freeman 2005).

693 Similar difficulties for correlating proteases and diet have been evidenced also in fish (German

694 et al. 2010), probably because all animals need protein, so selection should not be strong for low

695 protein-processing capability, and with the fact that herbivores have compensatorily higher

696 biochemical capacity (Karasov et al. 2011). In contrast, positive correlation of other digestive

697 enzymes (e.g. amylase) and diet are usual in very different groups, such as insects (Inomata and

698 Nakashima 2008), crustaceans (Pavasovic et al. 2007), and humans (Perry et al. 2007).

699

\subsection{Trypsins and digestive flexibility}

701

702 Feeding rate and digestive efficiency are two parameters of nutritional and ecological

703 importance (Karasov et al. 2011). Feeding rate in spiny lobsters is quite limited compare with

704 other crustaceans due to small foregut capacity, long foregut clearing time and slow appetite

705 revival (Simon and Jeff 2008), thus digestive efficiency of a single ration (at night) is expected

706 to be high. This partially relies on efficient mechanisms for mechanical (mouthparts, gastric

707 mill) and chemical digestion (enzymes). Trypsin accounts for around $60 \%$ of proteolysis of

708 dietary proteins in Panulirus argus (Perera et al. 2008a). Considerations of evolutionary

709 economic design suggest that enzymatic capacities should be only slightly in excess of their

710 corresponding loads (Karasov et al. 2011), but excess of trypsin enzymes would lie behind the

711 capacity of spiny lobster for switching to more abundant prey items in the environment without

712 impacting protein digestion efficiency. High amounts of trypsin enzymes in the gastric chamber

713 of fasting spiny lobsters, in addition to the ones secreted after feeding (Simon 2009; Perera et al.

714 2012b), may indicate the need for excess enzymes in anticipation to feeding on preys with high

715 protein content, but of unexpected quality.

716

717 While excess of trypsin expression and secretion may provide a general mechanism to cope

718 sudden changes in dietary protein quality (e.g. when switching to most abundant prey items in 
719 the environment), differences in specificity or cleavage ability among isoforms in P. argus

720 (Perera et al. 2012a) may provide additional flexibility. Moreover, some degree of physiological

721 flexibility may also occur by adapting the production of trypsins to a particular dietary

722 composition. Although proteins in the natural diet of $P$. argus and other spiny lobsters are

723 supposed to be highly digestible and a great adaptation capacity may be not necessary, some

724 results suggest that this capacity is present. In the spiny lobster Jasus edwardsii, the trypsin

725 activity tended to be lower in specimens fed with fresh mussel than formulated feeds (Simon

726 and Jeffs 2011), indicating perhaps an adaptation in response to lower digestibility of the

727 formulated feeds. The protein source (animal $v s$. vegetal) in formulated feeds also differentially

728 affects the expression and secretion of trypsins in P. argus (Perera et al. 2005; Perera et al.

729 2012b). This flexibility is poorly understood in terms of ecological significance. From studies in

730 larvae of other crustaceans it is well known that greater enzymatic flexibility occurs in

731 herbivorous species (Jones et al. 1997). Among invertebrates, flexibility in digestive enzymes

732 has been studied in detail in some insects such as Lepidoptera. Lepidopteran insects employ

733 different strategies to deal with plant inhibitors (PI) such as the expression of inhibitor-

734 insensitive proteases, over-expression of constitutive proteases to outnumber inhibitors present

735 in the digestive tract, induction of proteases capable of degrading the PI, or switching to

736 enzymes with altered substrate specificity such as the up-regulation of chymotrypsin-like

737 activity (Jongsma and Bolter, 1997; Spit et al. 2014).

738

739 Gene copy number variations and single-nucleotide polymorphisms are sources of phenotypic

740 variation in digestive biochemistry (Karasov et al. 2011). While these processes are known to

741 occur in P. argus trypsins (Perera et al. 2010b, 2012a), we are just starting to understand how

742 these could provide an adaptive value and some degree of digestive flexibility. It is feasible than

743 high basal and postprandial trypsin activity (Perera et al. 2008a; Perera et al. 2010a), difference

744 in activity, cleavage ability and other functional properties among isoforms (Perera et al.

745 2012a), as well as difference in expression rate and responsiveness to dietary proteins among

746 isoforms (Perera et al. 2012b), may provide the digestive flexibility required by lobsters to meet

747 their high protein physiological needs with a varied diet.

\section{Open issues}

751 Trypsin enzymes are not responsible of all protein digestion in crustaceans since other endo-

752 and exo-proteinases are deeply involved (Muhlia-Almazán et al. 2008; Sainz and Córdova-

753 Murueta 2009). However, trypsin account for most of the protein hydrolysis in P. argus (Perera

754 et al. 2008a) and it is the most studied P. argus enzyme to date, thus constituting a good model 
755 for assessing the digestive adaptation of this crustacean to its feeding ecology. Unfortunately,

756 molecular or even biochemical information about trypsins in spiny lobsters, and other

757 crustaceans, is available just for few species. Although this review is focused on studies using

758 one spiny lobsters species as a model organism, it provides baseline information and highlights

759 important but poorly studied issues in crustaceans in general. Information in other spiny lobsters

760 and crustaceans on trypsin isoenzymes richness, molecular and biochemical difference among

761 isoforms, molecular evolution, and the response of these enzymes to feeding, would lead to a

762 generalized model of trypsin evolution and regulation in crustaceans in relation to their feeding

763 ecology. Finally, although the aquaculture of spiny lobsters is currently a growing activity

764 (Phillips and Matsuda 2011), lobsters are still fed exclusively on fresh fishery by-catches due to

765 the absence of suitable artificial feeds. Major difficulties with the artificial feeding in spiny

766 lobsters have been associated with deficiencies in protein digestion and utilization (Williams

767 2007). These issues should be further addressed via the capacity of spiny lobsters to deal with

768 less digestible/soluble proteins and very different feed formats (e.g. dry, particulate) respect to

769 their natural diet.

770

771

\section{Acknowledgements}

772

773 Most of the work outlined on this topic was supported by the International Foundation for

774 Science (no. A/4306-1 and No. A/4306-2) granted to EP, the Agencia Española de Cooperación

775 Internacional/Asociación Universitaria Iberoamericana de Postgrado (AUIP/AECI) from Spain,

776 and the Program 'Doctorado Iberoamericano en Ciencias' at the University of Cadiz, Spain. 


\section{References}

Aguila J, Cuzon G, Pascual C, Domingues PM, Gaxiola G, Sánchez A, Maldonado T, Rosas C (2007) The effects of fish hydrolysate (CPSP) level on Octopus maya (Voss and Solis) diet: Digestive enzyme activity, blood metabolites, and energy balance. Aquaculture 273:641-655

783

784

785

786

787

788

789

790

791

792

793

794

Ahsan MM, Watabe S (2001) Kinetic and structural properties of two isoforms of trypsin isolated from the viscera of Japanese anchovy, Engraulis japonicus. J Protein Chem 20:49-58

Anheller JE, Hellgren L, Karlstam B, Vincent J (1989) Biochemical and biological profile of a new enzyme preparation from Antarctic krill (E. superba) suitable for debridement of ulcerative lesions. Arch Dermatol Res 281:105-110

Barclay MC, Irvin SJ, Williams KC, Smith DM (2006) Comparison of diets for the tropical spiny lobster Panulirus ornatus: astaxanthin-supplemented feeds and mussel flesh. Aquacult Nutr 12:117-125

Barret A, Rawlings N, Woessner J (1998) Handbook of proteolytic enzymes (2nd Ed) Academic Press, San Diego, 1666 pp

Blakemore D, Williams S, Lehane MJ (1995) Protein stimulation of trypsin secretion from the opaque zone midgut cells of Stomoxys calcitrans. Comp Biochem Physiol 110B:301-307

Borovsky D (2003) Biosynthesis and Control of Mosquito Gut Proteases. IUBMB Life 55:435441

Bougatef A (2013) Trypsins from fish processing waste: characteristics and biotechnological applications - comprehensive review. J Clean Prod 57:257-265

Bragado MJ, Groblewski GE, Williams JA (1998) Regulation of protein synthesis by cholecystokinin in rat pancreatic acini involves PHAS-I and the p70 S6 kinase pathway. Gastroenterology 115:733-42

Brandon MC, Pennington JE, Isoe J, Zamora J, Schillinger AS, Miesfeld RL (2008) TOR signaling is required for amino acid stimulation of early trypsin protein synthesis in the midgut of Aedes aegypti mosquitoes. Insect Biochem Molec 38:916-922

Brivanlou AH, Darnell JE (2002) Signal transduction and the control of gene expression. Science 295:813-818

Brockeroff H, Hoyle RJ, Hwang PC (1970) Digestive enzymes of the American lobster (Homarus americanus). J Fish Res Bd Canada 27:1357-1370

Buddington RK, Krogdahl Å (2004) Hormonal regulation of the fish gastrointestinal tract. Comp Biochem Physiol 139A:261-271 
813 Cahu CL, Rønnestad I, Grangiera V, Zambonino-Infante JL (2004) Expression and activities of

814 pancreatic enzymes in developing sea bass larvae (Dicentrarchus labrax) in relation to

815 intact and hydrolyzed dietary protein; involvement of cholecystokinin. Aquaculture

$816 \quad 238: 295-308$

817 Carrillo O, Forrellat-Barrios A, Guerrero-Galván S, Vega-Villasante F (2007) A review of

818 digestive enzyme activity in penaeid shrimps. Crustaceana 80:257-275

819 Celis-Gerrero LE, García-Carreño FL, Navarrete del Toro MA (2004) Characterization of

820 proteases in the digestive system of spiny lobster (Panulirus interruptus). Mar Biotechnol

$821 \quad 6: 262-269$

822 Chen H, Zhu YC, Whitworth RJ, Reese JC, Chen MS (2013) Serine and cysteine protease-like

823 genes in the genome of a gall midge and their interactions with host plant genotypes.

$824 \quad$ Insect Biochem Molec 43:701-711

825 Chow S, Suzuki S, Matsunaga T, Lavery S, Jeffs A, Takeyama H (2011) Investigation on

826 natural diets of larval marine animals using peptide nucleic acid-directed. Polymerase

827 Chain Reaction clamping. Mar Biotechnol 13:305-313

828 Colinas-Sánchez F, Briones-Foorzan P (1990) Feeding of the spiny lobsters Panulirus guttatus

829 and P. argus in the Mexican Caribbean. Inst Cienc Limnol Univ Nac Auton Mex 17:89-

$830 \quad 106$

831 Comeau SR, Gatchell DW, Vajda S, Camacho CJ (2004a) ClusPro: an automated docking and

832 discrimination method for the prediction of protein complexes. Bioinformatics 20:45-50

833 Comeau SR, Gatchell DW, Vajda S, Camacho CJ (2004b) ClusPro: a fully automated algorithm

834 for protein-protein docking. Nucleic Acids Res 32: W96-W99

835 Córdova-Murueta JH, García-Carreño F (2002) Nutritive value of squid and hydrolyzed protein

836 supplement in shrimp feed. Aquaculture 210:371-384

837 Cox C, Hunt JH, Lyons WG, Davis GE (1997) Nocturnal foraging of the Caribbean spiny

838 lobster, Panulirus argus on off shore reef of Florida, USA. Mar Freshwater Res 48:671-

$839 \quad 679$

840 de Albuquerquee-Cavalcanti C, García-Carreño FL, Navarrete del Toro MA (2002) Trypsin and

841 trypsin inhibitors from penaeid shrimp. J Food Biochem 26:233-251

842 Díaz-Mendoza M, Ortego F, García de Lacoba M, Magaña C, de la Poza M, Farinós GP,

843 Castañera P, Hernández-Crespo P (2005) Diversity of trypsins in the Mediterranean corn

$844 \quad$ borer Sesamia nonagrioides (Lepidoptera: Noctuidae), revealed by nucleic acid

845 sequences and enzyme purification. Insect Biochem Mol Biol 35:1005-1020

846 Drummond DA, Bloom JD, Adami C, Wilke CO, Arnold FH (2005) Why highly expressed

847 proteins evolve slowly. Proc Natl Acad Sci USA 102:14338-14343 
Einarsson S, Davies PS, Talbot C (1997) Effect of exogenous cholecystokinin on the discharge of the gallbladder and the secretion of trypsin and chymotrypsin from the pancreas of the Atlantic salmon, Salmo salar L. Comp Biochem Physiol 117C:63-67

Favrel P, Kegel G, Sedlmeier D, Keller R, van Wormhoudt A (1991) Structure and biological activity of crustacean gastrointestinal peptides identified with antibodies to gastrin/cholecystokinin. Biochimie 73:1233-1239

Fernández I, Oliva M, Carrillo O, VanWormhoudt A (1997) Digestive enzyme activities of Penaeus notialis during reproduction and molting cycle. Comp Biochem Physiol 118A:1267-1271

Fernández-Gimenez AV, García-Carreño FL, Navarrete del Toro MA, Fenucci JL (2001) Digestive proteinases of red shrimp Pleoticus muelleri (Decapoda, Penaeoidea): partial characterization and relationship with molting. Comp Biochem Physiol 130B:331-338

Hedstrom L (1996) Trypsin: A case study in the structural determinants of enzyme specificity.

Fernández-Gimenez AV, García-Carreño FL, Navarrete del Toro MA, Fenucci JL (2002) Digestive proteinases of Artemesia longinaris (Decapoda, Penaeidae) and relationship with molting. Comp Biochem Physiol 132B:593-598

Figarella C, Negri GA, Guy O (1975) The two human trypsinogens. Inhibition spectra of the two human trypsins derived from their purified zymogens. Eur J Biochem 53:457-463

Fodor K, Harmat V, Hetényi C, Kardos J, Antal J, Perczel A, Patthy A, Katona G, Gráf L (2005) Extended intermolecular interactions in a serine protease-canonical inhibitor complex account for strong and highly specific inhibition. J Mol Biol 350:156-169

Galgani F, Nagayama F (1987) Digestive proteinases in the Japanese spiny lobster Panulirus japonicus. Comp Biochem Physiol 87B:889-893

German DP, Nagle BC, Villeda JM, Ruiz AM, Thomson AW, Contreras-Balderas S, Evans DH (2010) Evolution of herbivory in a carnivorous clade of minnows (Teleostei: Cyprinidae): effects on gut size and digestive physiology. Physiol Biochem Zool 83:1-18

Graf R, Lea AO, Briegel H (1998) A temporal profile of the endocrine control of trypsin synthesis in the yellow fever mosquito, Aedes aegypti. J Insect Physiol 44:451-454

Green GM, Miyasaka K (1983) Rat pancreatic response to intestinal infusion of intact and hydrolyzed protein. Am J Physiol Gastrointest Liver Physiol 245:G394-G398

Hara H, Hashimoto N, Akatsuka N, Kasai T (2000) Induction of pancreatic trypsin by dietary amino acids in rats: Four trypsinogen isozymes and cholecystokinin messenger RNA. J Nutr Biochem 11:52-59 Biol Chem 377:465-470 
Hehemann JH, Redecke L, Murugaiyan J, von Bergen M, Betzel C, Saborowski R (2008) Autoproteolytic stability of a trypsin from the marine crab Cancer pagurus. Biochem Bioph Res Co 370:566-571

Herrera A, Díaz-Iglesias E, Brito R, Gonzáles G, Gotera G, Espinosa J, Ibarzábal D (1991) Alimentación natural de la langosta Panulirus argus en la región de los Indios (Plataforma SW de Cuba) y su relación con el bentos. Rev Invest Mar 12:172-182

Hickman RW, Illingworth J (1980) Condition cycle of the green-lipped mussel Perna canaliculus in New Zealand. Mar Biol 60:27-38

Hira T, Hara H, Kasai T (1997) Stimulation of exocrine pancreatic secretion by soybean trypsin inhibitor does not depend on the masking of luminal trypsin activity in rats that have bilepancreatic juice diverted into the ileum. Pancreas 15:285-290

Hirota M, Ohmuraya M, Baba H (2006) The role of trypsin, trypsin inhibitor, and trypsin receptor in the onset and aggravation of pancreatitis. J Gastroenterol 41:832-836

Holloway AK, Lawniczak MKN, Mezey JG, Begun DJ, Jones CD (2007) Adaptive gene expression divergence inferred from population genomics. PLoS Genet 3:2007-2013

Huber R, Kukla D, Bode W, Schwager P, Bartels K, Deisenhofer J, Steigemann W (1974) Structure of the complex formed by bovine trypsin and bovine pancreatic trypsin inhibitor II. Crystallographic refinement at 1.9 ̊̊ resolution. J Mol Biol 89:73-101

Hughes BL, Suniga RG, Yardley DG (1994) Influence of amylase genotypes on growth rate and feed conversion of chickens. Poultry Sci 73:953-957

903

Hurst LD (2002) The Ka/Ks ratio: diagnosing the form of sequence evolution. Trends Genet

904 $18: 486-487$

905

Huvet A, Daniel JY, Quéré C, Dubois S, Prudence M, Van Wormhoudt A, Sellos D, Samain JF, Moal J (2003) Tissue expression of two $\alpha$-amylase genes in the Pacific oyster Crassostrea gigas. Effects of two different food rations. Aquaculture 228:321-333

Huvet A, Jeffroy F, Fabioux C, Daniel JY, Quillien V, Van Wormhoudt A, Moal J, Samain JF, Boudry P. Pouvreau (2008) Assocition among growh, food conguption-related traits:

911 Inomata N, Nakashima S (2008) Short 5'-flanking regions of the Amy gene of Drosophila

912 kikkawai affect amylase gene expression and respond to food environments. Gene

$913 \quad 412: 102-9$

914 Johnson SC, Ewart KV, Osborne JA, Delage D, Ross NW, Murray HM (2002) Molecular

915 cloning of trypsin cDNAs and trypsin gene expression in the salmon louse

916 Lepeophtheirus salmonis (Copepoda: Caligidae). Parasitol Res 88:789-796 
Johnston D, Freeman J (2005) Dietary preference and digestive enzyme activities as indicators of trophic resource utilization by six species of crab. Biol Bull 208:36-46

Johnston D, Hermans JM, Yellowlees D (1995) Isolation and characterization of a trypsin from the slipper lobster, Thenus orientalis (Lund). Arch Biochem Biophys 324:35-40

Johnston D, Ritar A, Thomas C, Jeffs A (2004) Digestive enzyme profiles of spiny lobster Jasus edwardsii phyllosoma larvae. Mar Ecol Prog Ser 275:219-230

Johnston DJ (2003) Ontogenetic changes in digestive enzyme activity of the spiny lobster, Jasus edwardsii (Decapoda; Palinuridae). Mar Biol 143:1071-1082

Jones DA, Kumlu M, Le Vay L, Fletcher DJ (1997) The digestive physiology of herbivorous, omnivorous and carnivorous crustacean larvae: a review. Aquaculture 155:285-295

Jongsma MA, Bolter C (1997) The adaptation of insects to plant protease inhibitors. J Insect Physiol 43:885-895

Jönsson E, Forsman A, Einarsdottir IE, Egnér E, Ruohonen K, Björnsson BT (2006) Circulating levels of cholecystokinin and gastrin-releasing peptide in rainbow trout fed different diets. Gen Comp Endocr 148:187-194

Karasov WH, Martínez del Rio C, Caviedes-Vidal E (2011) Ecological physiology of diet and digestive systems. Annu Rev Physiol 73:69-93

935

936

937

Kim HR, Meyers SP, Godber JS (1992) Purification and characterization of anionic trypsins from the hepatopancreas of crayfish Procambarus clarkii. Comp Biochem Physiol 103B:391-398

Kirpichnikov VS, Muske GA (1980) The adaptative value of biochemical polymorphism in animal and plant populations. Genetica 52/53:183-193

Kittaka J (1997) Culture of larval spiny lobsters: a review of work done in northern Japan. Mar Freshwater Res 48:923-930

Klein B, Le Moullac G, Sellos D, Van Wormhoudt A (1996) Molecular cloning and sequencing

Konturek SJ, Zabielski R, Konturek JW, Czarnecki J (2003) Neuroendocrinology of the 
Koven W, Rojas-García CR, Finn RN, Tandler A, Rønnestad I (2002) Stimulatory effect of ingested protein and/or free amino acids on the secretion of the gastro-endocrine hormone cholecystokinin and on tryptic activity, in early-feeding herring larvae, Clupea harengus. Mar Biol 140:1241-1247

Kozakov D, Beglov D, Bohnuud T, Mottarella S, Xia B, Hall DR, Vajda S (2013) How good is automated protein docking? Proteins 81:2159-216

Kozakov D, Brenke R, Comeau SR, Vajda S (2006) PIPER: An FFT-based protein docking program with pairwise potentials. Proteins 65:392-406

Kvamme BO, Kongshaug H, Organisation FN (2005) Organization of trypsin genes in the salmon louse (Lepeophtheirus salmonis, Crustacea, copepoda) genome. Gene 352:63-74

Lalana R, Ortiz M (1991) Contenido estomacal de puérulos y post-puérulos de la langosta Panulirus argus en el Archipiélago de los Canarreos, Cuba. Rev Invest Mar 12:107-116 B, Clark AG (2008) Evolution of protein-coding genes in Drosophila. Trends Genet 24:114-23

968

Le Moullac G, Klein B, Sellos D, Van Wormhoudt A (1996) Adaptation of trypsin, chymotrypsin and amylase to casein level and protein source in Penaeus vannamei (Crustacea, Decapoda). J Exp Mar Biol Ecol 208:107-125

972

973

974

Le Vay L, Jones DA, Puello-Cruz AC, Sangha RS, Ngamphongsai C (2001) Digestion in

relation to feeding strategies exhibited by crustacean larvae. Comp Biochem Physiol 128A:623-630

Lehane MJ, Blakemore D, Williams S, Moffatt MR (1995) Regulation of digestive enzyme levels in insects. Comp Biochem Physiol 110B:285-289

Liao D (1999) Concerted evolution: molecular mechanism and biological implications. Am J Hum Genet 64:24-30

Lipcius RN, Herrnkind WF (1982) Molt cycle alterations in behavior, feeding and diel rhythms of a decapod crustacean, the spiny lobster Panulirus argus. Mar Biol 68:241-252

Lopes AR, Juliano MA, Juliano L, Terra WR (2004) Coevolution of Insect Trypsins and

987 Marx JM, Herrnkind WF (1985) Macroalgae (Rhodophyta: Laurecia spp.) as habitat for young 988 juvenile spiny lobsters, Panulirus argus. B Mar Sci 36:423-431 
Mazumdar-Leighton S, Broadway RM (2001) Transcriptional induction of diverse midgut trypsins in larval Agrotis ipsilon and Helicoverpa zea feeding on the soybean trypsin Inhibitor. Insect Biochem Mol Biol 31:645-657

Meyer JH, Kelly GA (1976) Canine pancreatic responses to intestinally perfused proteins and protein digests. Am J Physiol 231:682-691

Moffatt M, Blakemore D, Lehane MJ (1995) Studies on the synthesis and secretion of trypsin in the midgut of Stomoxys calcitrans. Comp Bioehem Physiol 110B: 291-300

Molnár T, Vörös J, Szeder B, Takáts K, Kardos J, Katona G, Gráf L (2013) Comparison of complexes formed by a crustacean and a vertebrate trypsin with bovine pancreatic trypsin inhibitor- the key to achieving extreme stability? FEBS J 280:5750-5763

Muhlia-Almazán A, García-Carreño FL, Sánchez-Paz JA, Yepiz-Plascencia G, PeregrinoUriarte AB (2003) Effects of dietary protein on the activity and mRNA level of trypsin in the midgut gland of the white shrimp Penaeus vannamei. Comp Biochem Physiol 135B:373-383

Muhlia-Almazán A, Sánchez-Paz A, García-Carreño FL (2008) Invertebrate trypsins: a review. J Comp Physiol 178B:655-672

Nègre N, Brown CD, Ma L, Bristow CA, Miller SW, Wagner U, Kheradpour P, Eaton ML, Loriaux P, Sealfon R, Li Z, Ishii H, Spokony RF, Chen J, Hwang L, Cheng C, Auburn RP, Davis MB, Domanus M, Shah PK, Morrison CA, Zieba J, Suchy S, Senderowicz L, Victorsen A, Bild NA, Grundstad, AJ, Hanley D, MacAlpine DM, Mannervik M, Venken K, Bellen H, White R, Gerstein M, Russell S, Grossman RL, Ren B, Posakony JW, Kellis M, White KP (2011) A cis-regulatory map of the Drosophila genome. Nature 471:527531

Nelson K, Hedgecock D (1980) Enzyme polymorphism and adaptive strategy in the decapod crustacea. Am Nat 116:238-280

Noriega FG, Colonna AE, Wells MA (1999) Increase in the size of the amino acid pool is sufficient to activate translation of early trypsin mRNA in Aedes aegypti midgut. Insect Biochem Molec 29:243-247

Noriega FG, Wells MA (1999) A molecular view of trypsin synthesis in the midgut of Aedes aegypti. J Insect Physiol 45:613-620

Noriega FG, Wang XY, Pennington JE, Barillas-Mury CV, Wells MA (1996) Early trypsin, a female-specific midgut protease in Aedes aegypti: isolation, amino-terminal sequence determination, and cloning and sequencing of the gene. Insect Biochem Molec Biol 26:119-126

Northrup JH, Kunitz M (1931) Isolation of protein crystals possessing tryptic activity. Science $73: 262-263$ 
Northrup JH, Kunitz M, Herriott RM (1948) Crystalline enzymes. 2nd ed, Columbia University Press, New York

1027 Nyberg P, Ylipalosaari M, Sorsa T, Salo T (2006) Trypsins and their role in carcinoma growth. Exp Cell Res 312:1219-1228

Ohlsson K, Tegner H (1973) Anionic and cationic dog trypsin: Isolation and partial characterization. Biochim Biophys Acta 317:328-337

Owyang C (1994) Negative feedback control of exocrine pancreatic secretion: role of cholecystokinin and cholinergic pathway. J Nutr 124:1321S-1326S

Page MJ, Di Cera E (2008) Serine peptidases: classification, structure and function. Cell Mol Life Sci 65:1220-1236

Patthy L (1999) Genome evolution and the evolution of exon shuffling: a review. Gene 238:103-114

Pavasovic A, Anderson AJ, Mather PB, Richardson NA (2007) Effect of a variety of animal, plant and single cell-based feed ingredients on diet digestibility and digestive enzyme activity in redclaw crayfish, Cherax quadricarinatus (Von Martens 1868). Aquaculture 272:564-572

Perera E, Fraga I, Carrillo O, Díaz-Iglesias E, Cruz R, Báez M, Galich G (2005) Evaluation of practical diets for the Caribbean spiny lobster Panulirus argus (Latreille, 1804): effects of protein sources on substrate metabolism and digestive proteases. Aquaculture 244:251262

Perera E, Moyano FJ, Díaz M, Perdomo-Morales R, Montero-Alejo V, Alonso-Jiménez E, Carrillo O, Galich G (2008a) Polymorphism and partial characterization of digestive enzymes in the spiny lobster Panulirus argus. Comp Biochem Physiol 150B:247-254

Perera E, Moyano FJ, Díaz M, Perdomo-Morales R, Montero V, Rodríguez-Viera L, Alonso E, Carrillo O, Galich G (2008b) Changes in digestive enzymes through developmental and molt stages in the spiny lobster, Panulirus argus. Comp Biochem Physiol 151B:250-256

Perera E, Moyano FJ, Rodríguez-Viera L, Cervantes A, Martínez-Rodríguez G, Mancera JM (2010a) In vitro digestion of protein sources by crude enzyme extracts of the spiny lobster

1058 Perera E, Rodríguez-Casariego J, Rodríguez-Viera L, Calero J, Perdomo-Morales R, Mancera Panulirus argus (Latreille, 1804) hepatopancreas with different trypsin isoenzyme patterns. Aquaculture 310:178-185

Perera E, Pons T, Hernández D, Moyano FJ, Martínez-Rodríguez G, Mancera JM (2010b) New JM (2012a) Lobster (Panulirus argus) hepatopancreatic trypsin isoforms and their digestion efficiency. Biol Bull 222:158-170 

G, Mancera JM (2012b) Dietary protein quality differentially regulates trypsin enzymes at the secretion and transcription levels in the lobster (Panulirus argus) by distinct signaling pathways. J Exp Biol 215:853-862

Perona JJ, Craik CS (1995) Structural basis of substrate specificity in the serine proteases. Protein Sci 4:337-360

Perona JJ, Tsu CA, Craik CS, Fletterick RJ (1997) Crystal structure of an ecotincollagenase complex suggests a model for recognition and cleavage of the collagen triple helix. Biochemistry 36:5381-5392

Perona JP, Craik CS (1997) Evolutionary divergence of substrate specificity within the chymotrypsin-like serine protease fold. J Biol Chem 272:29987-29990

Perry GH, Dominy NJ, Claw KG, Lee AS, Fiegler H, Redon R, Werner J, Villanea FA, Mountain JL, Misra R, Carter NP, Lee C, Stone AC (2007) Diet and the evolution of human amylase gene copy number variation. Nat Genet 39:1256-1260

Phillips B, Matsuda H (2011) A global review of spiny lobster aquaculture. In: Fotedar RK, Phillips BF (eds.) Recent Advances and New Species in Aquaculture. Blackwell Publishing Ltd, Oxford, pp 22-84

Psochiou E, Sarropoulou E, Mamuris Z, Moutou KA (2007) Sequence analysis and tissue expression pattern of Sparus aurata chymotrypsinogens and trypsinogen. Comp Biochem Physiol 147B:367-377

Puigserver A, Desnuelle P (1971) Identification of an anionic trypsinogen in bovine pancreas. Biochim Biophys Acta 236:499-502

Rascón AA, Gearin J, Isoe J, Miesfeld RL (2011) In vitro activation and enzyme kinetic analysis of recombinant midgut serine proteases from the dengue vector mosquito Aedes

1090 Ravallec-Plé R, van Wormhoudt A (2003) Secretagogue activities in cod (Gadus morhua) and shrimp (Penaeus aztecus) extracts and alcalase hydrolysates determined in AR4-2J pancreatic tumour cells. Comp Biochem Physiol 134B:669-679

Resch-Sedlmeier G, Sedlmeier D (1999) Release of digestive enzymes from the crustacean hepatopancreas: effect of vertebrate gastrointestinal hormones. Comp Biochem Physiol 123B:187-192 
Rungruangsak-Torrissen K, Pringle GM, Moss R, Houlihan DF (1998) Effects of varying rearing temperatures on expression of different trypsin isoenzymes, feed conversion efficiency and growth in Atlantic salmon (Salmo salar L.). Fish Physiol Biochem 19: 247-255.

1100 Rungruangsak-Torrissen K, Carter CG, Sundby A, Berg A, Houlihan DF (1999) Maintenance ration, protein synthesis capacity, plasma insulin and growth of Atlantic salmon (Salmo

Rungruangsak-Torrissen K, Male R (2000) Trypsin isozymes: Development, digestion and structure. In: Haard NF, Simpson BK (eds) Seafood Enzymes, utilization and influence on post-harvest seafood quality. Marcel Dekker Inc, New York, 215-269 pp

Rungruangsak-Torrissen K (2012) Trypsin and its implementation for growth, maturation, and dietary quality assessment. In: Weaver K and Kelley C (eds) Trypsin: structure, biosynthesis and functions. Nova Science Publishers, Inc. New York, 1-59 pp.

Rypniewski WR, Perrakis A, Vorgias CE, Wilson KS (1994) Evolutionary divergence and conservation of trypsin. Protein Eng 7: 57-64

Saborowski R, Schatte J, Gimenez L (2012) Catalytic properties and polymorphism of serine endopeptidases from the midgut gland of the brown shrimp Crangon crangon (Decapoda, Caridea). Mar Biol 159:1107-1118

Sainz JC, Córdova-Murueta JH (2009) Activity of trypsin from Litopenaeus vannamei.

Aquaculture 290. 190-195

1117 Sainz JC, García-Carreño FL, Hernández-Cortés P (2004) Penaeus vannamei isotrypsins:

1118 purification and characterization. Comp Biochem Physiol 138B:155-162

1119 Sainz JC, García-Carreño FL, Sierra-Beltrán A, Hernández-Cortés P (2004) Trypsin synthesis and storage as zymogen in the midgut gland of the shrimp Litopenaeus vannamei. J Crust

1122 Sainz JC, García-Carreño FL, Córdova-Murueta JH, Cruz-Hernández P (2005) Penaeus vannamei (Boone, 1931) isotrypsins, genotype and modulation. J Exp Mar Biol Ecol 326:

1125 Sans MD, Tashiro M, Vogel NL, Kimball SR, D’Alecy LG, Williams JA (2006) Leucine activates pancreatic translational machinery in rats and mice through mTOR independently of CCK and insulin. J Nutr 136:1792-1799

1128 Sans MD, Williams JA (2002) Translational control of protein synthesis in pancreatic acinar cells. Int J Gastrointest Cancer 31:107-15 
1130 Saunders MI, Thompson PA, Jeffs AG, Säwström C, Sachlikidis N, Beckley LE, Waite AM (2012) Fussy feeders: phyllosoma larvae of the Western rock lobster (Panulirus cygnus)

1133 Savoie A, Le François NR, Lamarre SG, Blier PU, Beaulieu L, Cahu C (2011) Dietary protein 1134 hydrolysate and trypsin inhibitor effects on digestive capacities and performances during early-stages of spotted wolffish: Suggested mechanisms. Comp Biochem Physiol 158A:525-530

Schwarzenberger A, Zitt A, Kroth P, Mueller S, Von Elert E (2010) Gene expression and activity of digestive proteases in Daphnia: effects of cyanobacterial protease inhibitors. BMC Physiology 10:6

Shahidi F, Kamil YVAJ (2001) Enzymes from fish and aquatic invertebrates and their application in the food industry. Trends Food Sci Tech 12: 435-464

Smith DM, Williams KC, Irvin SJ (2005) Response of the tropical spiny lobster Panulirus ornatus to protein content of pelleted feed and to a diet of mussel flesh. Aquacult Nutr 11:209-217

Simon CJ (2009) Digestive enzyme response to natural and formulated diets in cultured juvenile spiny lobster, Jasus edwardsii. Aquaculture 294:271-281.

Simon CJ, Jeffs A (2008) Feeding and gut evacuation of cultured juvenile spiny lobsters, Jasus edwardsii. Aquaculture 280:211-219

Simon CJ, Jeffs A (2011) The effect of dietary carbohydrates on the growth response, digestive gland glycogen and digestive enzyme activities of early spiny lobster juveniles, Jasus edwardsii. Aquacult Nutr 17:613-626

Singer MV (1987) Pancreatic secretory response to intestinal stimulants: a review. Scand J Gastroenterol Suppl 139:1-13

Spit J, Zels S, Dillen S, Holtof M, Wynant N, Broeck JV (2014) Effects of different dietary

Soares TS, Watanabe RMO, Lemos FJA, Tanaka AS (2011) Molecular characterization of genes encoding trypsin-like enzymes from Aedes aegypti larvae and identification of digestive enzymes. Gene 489:70-75

1161 Srinivasan A, Giri AP, Gupta VS (2006) Structural and functional diversities in lepidopteran serine proteases. Cell Mol Biol Lett 11:132-154Staljanssens D, Azari EK, Christiaens O, Beaufays J, Lins L, Camp JV, Smagghe G (2011) The CCK(-like) receptor in the animal kingdom: Functions, evolution and structures. Peptides 32:607-619 
1165 Sweet RM, Wright HT, Janin J, Chothia CH, Blow DM (1974) Crystal structure of the complex 1166 of porcine trypsin with soybean trypsin inhibitor (Kunitz) at 2.6- $\AA$ resolution.

1167 Biochemistry 13:4212-4228

1168 Tamura K, Dudley J, Nei M, Kumar S (2007) MEGA4: Molecular evolutionary genetics

1169 analysis (MEGA) software version 4.0. Mol Biol Evol 24:1596-1599

1170 Taylor JS, Raes J (2004) Duplication and divergence: The evolution of new genes and old ideas.

$1171 \quad$ Annu Rev Genet 38:615-43

1172 Thimister PWL, Hopman WPM, Sloots CEJ, Rosenbusch G, Willems HL, Trijbels FJM, Jansen 1173 JBMJ (1996). Role of intraduodenal proteases in plasma cholecystokinin and 1174 pancreaticobiliary responses to protein and amino acids. Gastroenterology 110:567-575

1175 Teschke M, Saborowski R (2005) Cysteine proteinases substitute for serine proteinases in the 1176 midgut glands of Crangon crangon and Crangon allmani (Decapoda: Caridea). J Exp $1177 \quad$ Mar Biol Ecol 316:213-229

1178 Tillner R, Rønnestad I, Harboe T, Ueberschär B (2013) Hormonal control of tryptic enzyme 1179 activity in Atlantic cod larvae (Gadus morhua): Involvement of cholecystokinin during 1180 ontogeny and diurnal rhythm. Aquaculture 402-403:133-140

1181 Toyota E, Iyaguchi D, Sekizaki H, Itoh K, Tanizawa K (2007) Kinetic properties of three 1182 isoforms of trypsin isolated from the pyloric caeca of chum salmon (Oncorhynchus keta). 1183 Biol Pharm Bull 30:1648-1652

1184 Torrissen KR (1987) Genetic variation of trypsin-like isozymes correlated to fish size of $1185 \quad$ Atlantic salmon (Salmo salar). Aquaculture 62: 1-10

1186 Torrissen KR (1991) Genetic variation in growth rate of Atlantic salmon with different trypsin1187 like isozyme patterns. Aquaculture 93: 299-312

1188 Torrissen KR, Shearer KD (1992) Protein digestion, growth and food conversion in Atlantic salmon and Arctic charr with different trypsin-like isozyme patterns. J Fish Biol 41: 409415

Torrissen KR, Male R, Naevdal G (1993) Trypsin isozymes in Atlantic salmon, Salmo salar L.: studies of heredity, egg quality and effect on growth of three deferent populations. Aquac Fish Manage 24: 407-415

Torrissen KR, Lied E, Espe M (1994) Differences in digestion and absorption of dietary protein in Atlantic salmon (Salmo salar) with genetically different trypsin isoenzymes. J Fish Biol 45: 1087-1104.

Tsu CA, Craik CS (1998) Brachyurins. In: Barrett AJ, Rawlings ND, Woessner JF (eds) Handbook of Proteolytic Enzymes. Academic Press, San Diego, CA, USA, 25-30 pp

Tsu CA, Perona JJ, Fletterick RJ, Craik CS (1997) Structural basis for the broad substrate specificity of fiddler crab collagenolytic serine protease. Biochemistry 36:5393-5401 
van Acker GJD, Perides G, Steer ML (2006) Co-localization hypothesis: A mechanism for the intrapancreatic activation of digestive enzymes during the early phases of acute pancreatitis. World J Gastroenterol 12:1985-1990

van Hoef V, Breugelmans B, Spit J, Simonet G, Zels S, Billen J, Broeck JV (2011) Functional analysis of a pancreatic secretory trypsin inhibitor-like protein in insects: silencing effects resemble the human pancreatic autodigestión phenotype. Insect Biochem Molec 41:688695

van Wormhoudt A (1974) Variations of the level of the digestive enzymes during the intermolt cycle of Palaemon serratus: influence of the season and effect of the eyestalk ablation. Comp Biochem Physiol 49A:707-715

van Wormhoudt A, Favrel P, Guillaume J (1989). Gastrin/cholecystokinin-like post-prandial variations: quantitative and qualitative changes in the haemolymph of penaeids (Crustacea; Decapoda). J Comp Physiol 159:269-213

Vogt G, Stfcker W, Storeh V, Zwilling R (1989) Biosynthesis of Astacus protease, a digestive enzyme from crayfish. Histochemistry 91:373-381

Voytek P, Gjessing EC (1971) Studies of an anionic trypsinogen and its active enzyme from porcine pancreas. J Biol Chem 246:508-516

Walsh KA, Kauffman DL, Sampath-Kumar KSV, Neurath H (1964) On the structure and function of bovine trypsinogen and trypsin. Proc Natl Acad Sci USA 51:301-308

Walsh KA, Wilcox PE (1970) Serine proteinases. Meth Enzymol 19:31-41

Wang S, Magoulas C, Hickey D (1999) Concerted evolution within a trypsin gene cluster in Drosophila. Mol Biol Evol 16:1117-1124

Williams KC (2007) Nutritional requirements and feeds development for post-larval spiny lobster: a review. Aquaculture 263:1-14

Woodring J, Diersch S, Lwalaba D, Hoffmann KH, Meyering-Vos M (2009) Control of the release of digestive enzymes in the caeca of the cricket Gryllus bimaculatus. Physiol Entomol 34:144-151

Wray GA, Hahn MW, Abouheif E, Balhoff JP, Pizer M (2003) The evolution of transcriptional regulation in eukaryotes. Mol Biol Evol 20:1377-1419

Wu DD, Wang GD, Irwin DM, Zhang YP (2009) A profound role for the expansion of trypsinlike serine protease family in the evolution of hematophagy in mosquito. Mol Biol Evol 26:2333-2341

Wu Z, Jiang G, Xiang P, Xu H (2008) Anionic trypsin from North Pacific krill (Euphausia pacifica): purification and characterization. Int J Pept Res Ther14:113-120 
1235 Xiong B, Jacobs-Lorena M (1995) The black fly Simulium vittatum trypsin gene:

1236 characterization of the 5'-upstream region and induction by the blood meal. Exp Parasitol

$1237 \quad 81: 363-370$

1238 Zambonino-Infante JL, Cahu C (2007) Dietary modulation of some digestive enzymes and

1239 metabolic processes in developing marine fish: Applications to diet formulation.

$1240 \quad$ Aquaculture 268:98-105

1241 Zlatanos S, Laskaridis K, Sagredos A (2009) Determination of proximate composition, fatty

1242 acid content and amino acid profile of five lesser-common sea organisms from the

1243 Mediterranean Sea. Int J Food Sci Tech 44:1590-1594

1244

1245 
1246 Fig.1 Schematic representation of the main three trypsin isoenzyme patterns or phenotypes in

1247 the spiny lobster Panulirus argus, according to the presence of major isoforms in individual

1248 lobsters, as revealed in casein zymograms (Perera et al. 2008a, 2010a). Trypsin identity was

1249 corroborated by in-gel assays with specific proteinase inhibitors (Perera et al. 2008a). Lobsters

1250 with the three main trypsin isoenzymes are named phenotype A. Individuals lacking the trypsin

1251 isoenzyme of higher electrophoretic mobility are named phenotype B, while lobsters lacking the

1252 trypsin isoenzyme of middle electrophoretic mobility are named phenotype C. Above these

1253 three main isotrypsins, other serine (even trypsin-like) proteinases occur in gels, but notably less

1254 active and without a discernible pattern through individual lobsters (Perera et al. 2008a)

1255

1256 Fig. 2 Three-dimensional models of the most abundant Panulirus argus trypsin isoform, PaTry3

1257 (PMDB database: accession number PM0076232), showing (a) the two $\beta$-barrels (yellow)

1258 making up the fold, connecting $\alpha$-helices (red) and surface loops (green), the catalytic residues

1259 His74, Asp125 and Ser218 (His57, Asp102, Ser 195, chymotrypsin numbering), primary

1260 specificity residues [Asp212 (189, chymotrypsin numbering) residue near the base of the

1261 substrate-binding pocket to stabilize the positive charge of P1 Arg or Lys side chains, and the

1262 small residues Gly239 and Gly249 (216 and 226, chymotrypsin numbering) on one wall of the

1263 pocket to allow the access of bulky residues to the S1 site], and the calcium-binding site, and (b)

1264 predicted hydrophobic binding sites in loop 37 of lobster trypsin (PaTry3) to a proteinase

1265 inhibitor (SGTI accession no. 1KJ0, in green) using the docking approach when ranking models

1266 based on cluster size by the program ClusPro 2 (http://cluspro.bu.edu) (Comeau et al. 2004a,b;

1267 Kozakov et al. 2006, 2013), and the mapping of positively selected sites (Phe 52 and Phe 54) in

1268 loop 37 of PaTry3, showing they may play a role in more extended interactions with

1269 hydrophobic elements of larger inhibitors and presumably, of proteinaceos substrates in this

1270 variant of the enzyme. Site numbers start at the first residue of lobster PaTry3 trypsinogen

1271 (Perera et al. 2010a). Loops 37 and 60 are used according to the nomenclature in crayfish

1272 trypsin (Fodor et al. 2005). Loops 1 and 2 are according to vertebrate nomenclature (Perona and

1273 Craik 1995; Hedstrom 1996). Figures were generated with Open-Source PyMOL ${ }^{\mathrm{TM}}$ Molecular

1274 Graphics System, Version 1.6.x (Schrödinger, DeLano Scientific LLC, San Carlos, California,

1275 USA)

1276

1277 Fig. 3 Substrate-SDS-PAGE showing caseinolytic activity bands in digestive gland of

1278 individuals $P$. argus with low expression of trypsin transcripts PaTryla (GU338026.1) and

1279 PaTry2 (GU338028.1) as revealed by RT-qPCR assays. The central lane corresponds to an

1280 individual expressing all major transcripts, PaTry1a, PaTry2, and PaTry3 (GU338029.1). Black

1281 boxes indicate absence or low amount/activity of particular isoenzymes. Arrows on the left 
1282 indicate transcripts possibly matching with isoenzymes. PaTry3 is always highly expressed and

1283 putative corresponding isoenzyme is always present in activity gels. LMW: low molecular

1284 weight markers.

1285

1286 Fig. 4 Structural and functional diversification is better understood in Lepidoptera and fishes than in decapod crustaceans. NJ distance analysis tree showing trypsin isoform structural diversification in selected groups of insects, crustaceans, and fishes. Non-redundant trypsin sequences were aligned using the Clustal algorithm. The best-fit model of evolution (JTT+G, gamma shape parameter $=2.69)$ was selected and tree constructed with MEGA5 (Tamura et al. 2007). Topology robustness was tested with 1000 bootstrap replicates. Only bootstrap values higher than $50 \%$ are shown. Species and accession numbers are shown in the tree.

1294 Fig. 5 Proposed model for food-mediated regulation of trypsin enzymes during the feeding cycle in the spiny lobster Panulirus argus. Bold dotted lines represent constitutive processes and bold continuous lines represent inducible events. High expression and secretion of trypsins occur in fasted lobsters, suggesting an advantage of excess of enzyme in anticipation to feeding. During feeding, soluble intact proteins stimulate enzyme secretion to attain maximal activity in the gastric chamber four hour after ingestion. Through the progression of digestion, trypsin phenotype (composition of isoenzymes) significantly affects the efficiency of protein hydrolysis. Later, protein digestion end-products induce the expression of the most abundant isoforms (PaTry3) in the digestive gland, together with the constitutive expression of the other isoforms, most likely as preparation for the next feeding. Superscripts represent research papers where the indicated processes were studied in P. argus: ${ }^{1}$ Perera et al. $2008 \mathrm{a} ;{ }^{2}$ Perera et al. 2008b; ${ }^{3}$ Perera et al. 2010a; ${ }^{4}$ Perera et al. 2010b; ${ }^{5}$ Perera et al. 2012a; ${ }^{6}$ Perera et al. 2012b 
1321 FIG 1.

1322

1323

1374

\section{Trypsin phenotypes}

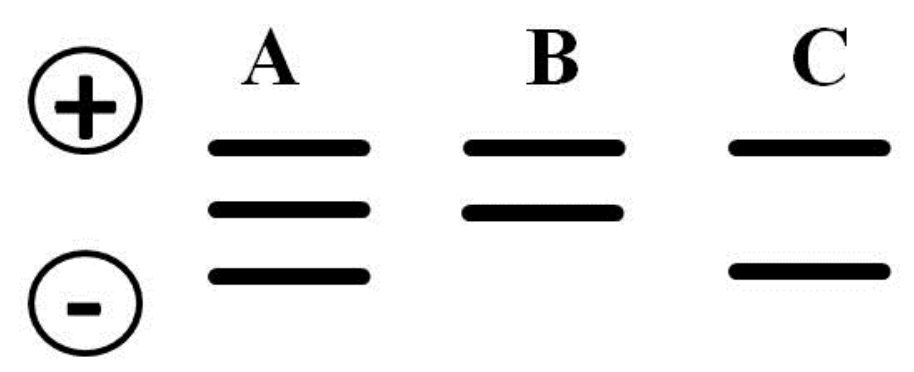

1331

1332

1333

1334

1335

1336

1337

1338

1339

1340

1341

1342

1343

1344

1345

1346 
1347 FIG 2.
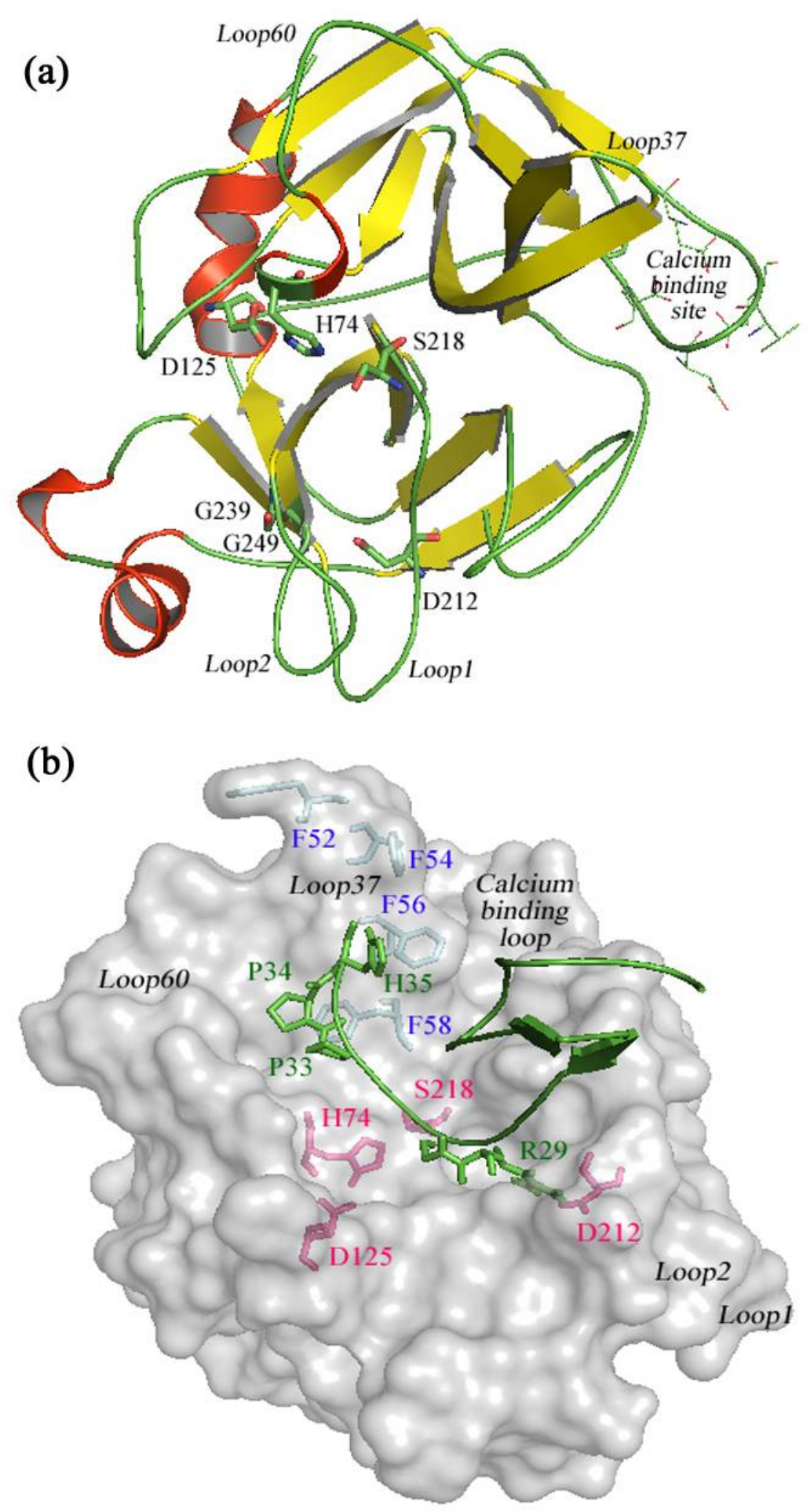
1373

1374 FIG 3.

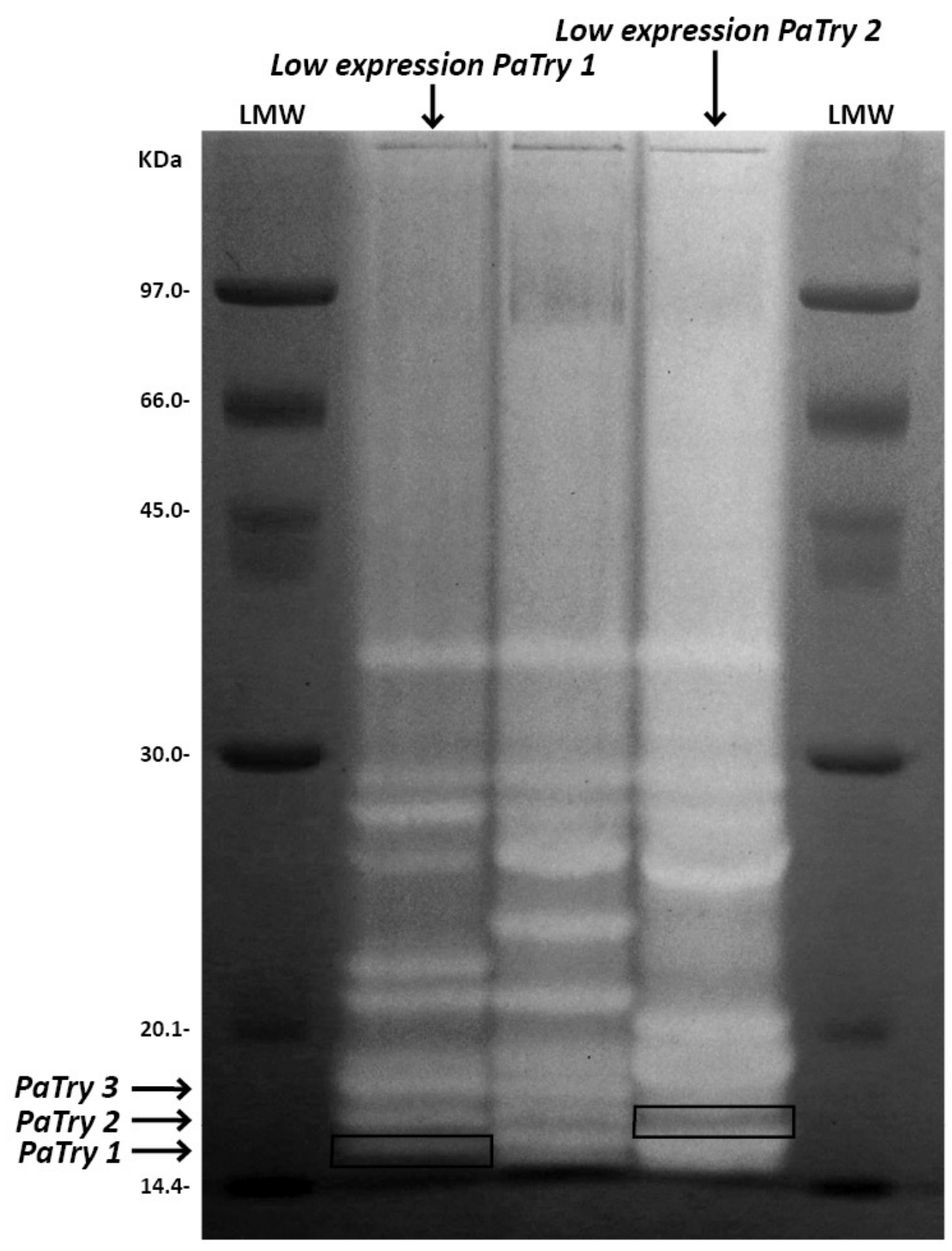

1375 


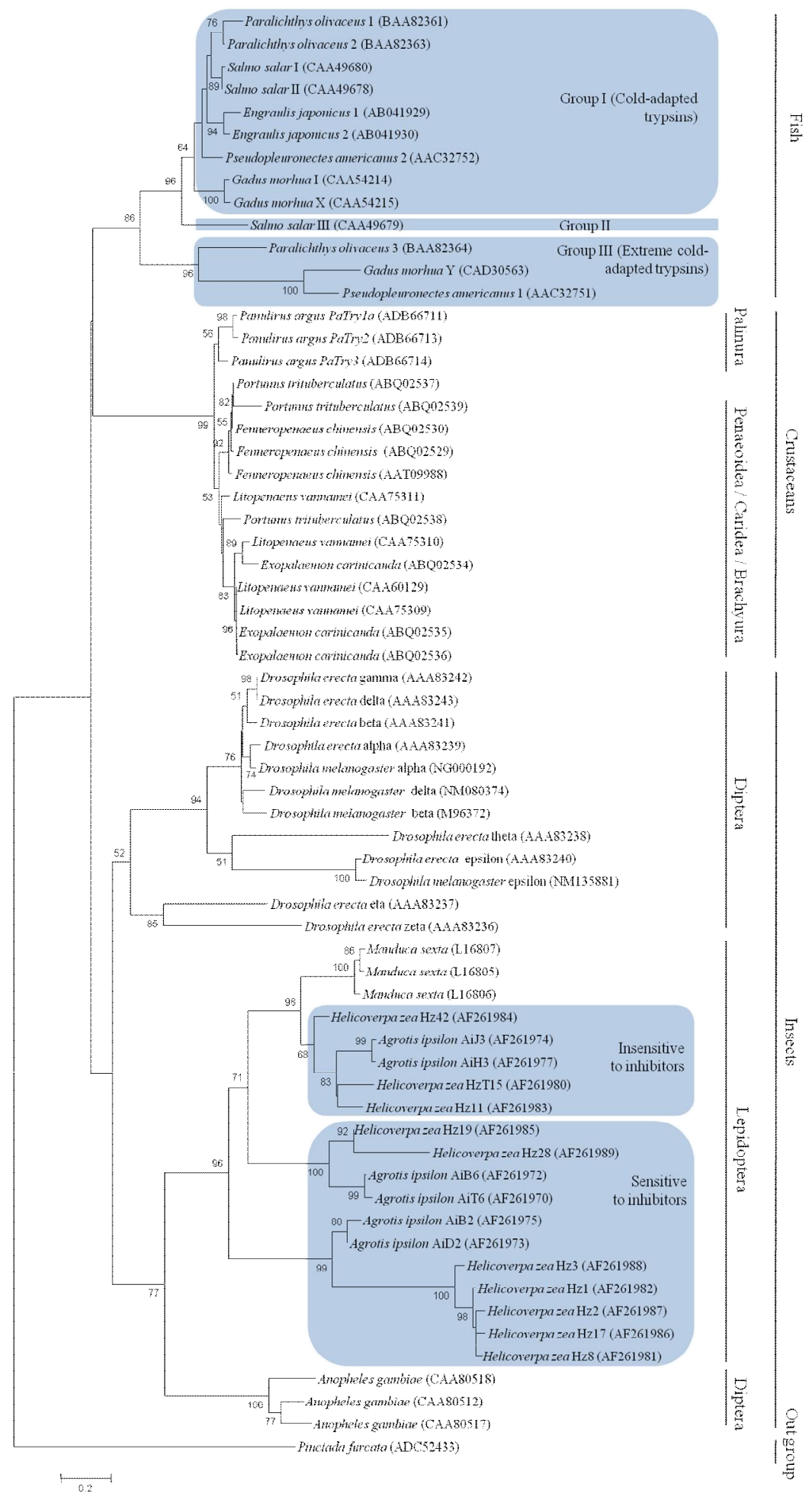

1381

1382

1383 


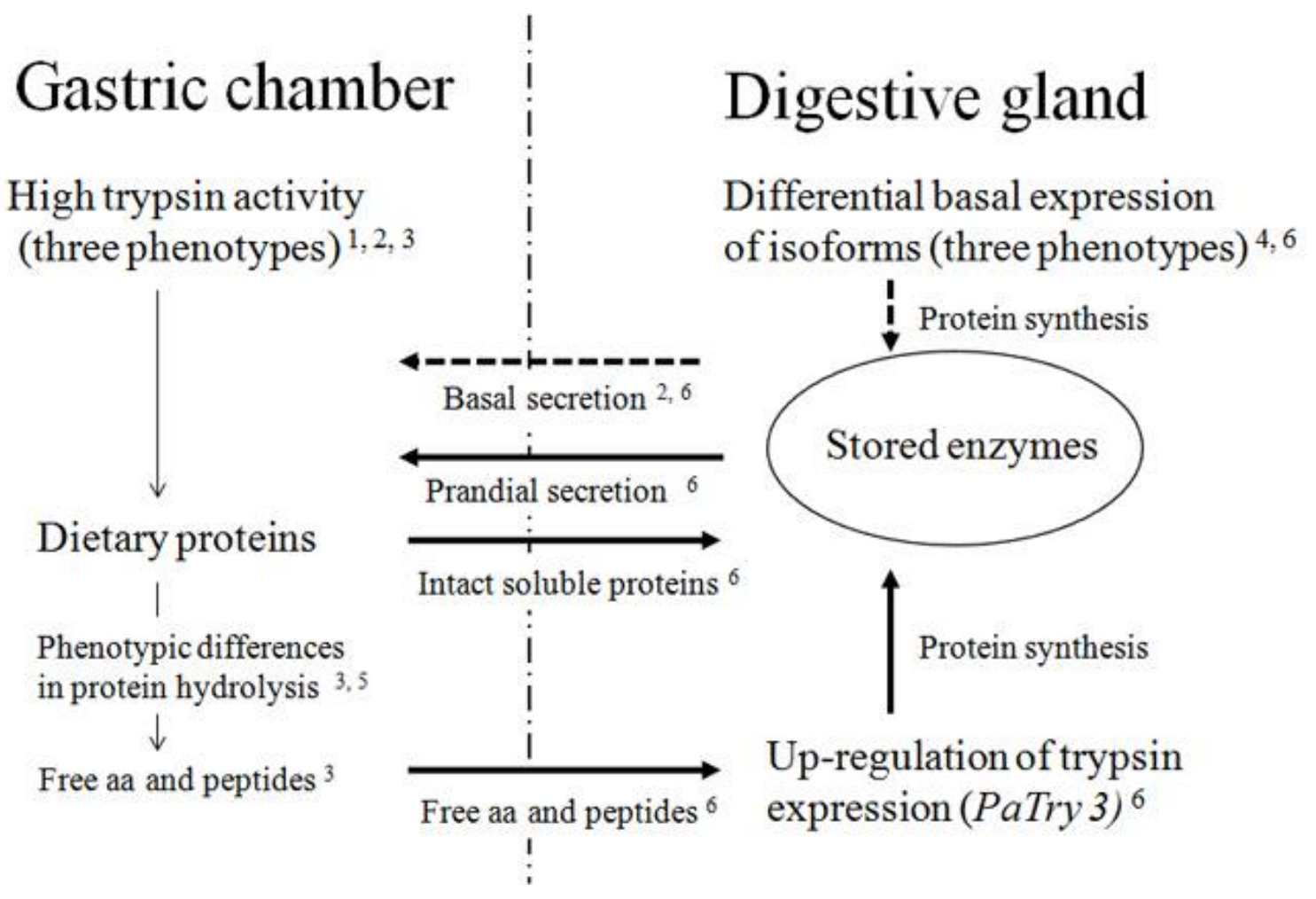

1387

1388 